\title{
Variations in chemical and physical properties of Amazon forest soils in relation to their genesis
}

\author{
C. A. Quesada ${ }^{1,6}$, J. Lloyd ${ }^{1}$, M. Schwarz ${ }^{2, *}$, S. Patiño ${ }^{3,4}$, T. R. Baker ${ }^{1}$, C. Czimczik $^{2,{ }^{* *}}$, N. M. Fyllas ${ }^{1}$, L. Martinelli ${ }^{5}$, \\ G. B. Nardoto $^{5}$, J. Schmerler ${ }^{2}$, A. J. B. Santos ${ }^{6,}$, M. G. Hodnett ${ }^{7}$, R. Herrera ${ }^{8}$, F. J. Luizão ${ }^{6}$, A. Arneth ${ }^{2, * * *}$, \\ G. Lloyd $^{2}$, N. Dezzeo ${ }^{8}$, I. Hilke ${ }^{2}$, I. Kuhlmann ${ }^{2}$, M. Raessler ${ }^{2}$, W. A. Brand ${ }^{2}$, H. Geilmann ${ }^{2}$, J. O. Moraes Filho ${ }^{6}$, \\ F. P. Carvalho ${ }^{6}$, R. N. Araujo Filho ${ }^{6}$, J. E. Chaves $^{6}$, O. F. Cruz Junior ${ }^{6}$, T. P. Pimentel ${ }^{6}$, and R. Paiva ${ }^{6}$ \\ ${ }^{1}$ Earth and Biosphere Institute, School of Geography, University of Leeds, Leeds, LS2 9JT, UK \\ ${ }^{2}$ Max-Planck-Institut fuer Biogeochemie, Jena, Germany \\ ${ }^{3}$ Instituto de Investigación de Recursos Biológicos, Alexander von Humboldt, Bogotá, Colombia \\ ${ }^{4}$ UMR-ECOFOG, INRA, 97310, Korou, French Guiana, France \\ ${ }^{5}$ Centro de Energia Nuclear na Agricultura, Piracicaba, Brazil \\ ${ }^{6}$ Institito Nacional de Pesquisas da Amazônia, Manaus, Brazil \\ ${ }^{7}$ Centre for Ecology and Hydrology, Wallingford, UK \\ ${ }^{8}$ Instituto Venezuelano de Investigaciones Científicas, Caracas, Venezuela \\ *now at: Fieldwork Assistance, Postfach 101022, 07710 Jena, Germany \\ *** now at: Department of Earth System Science, University of California, 2103 Croul Hall, Irvine, CA, 92697-3100, USA \\ **** now at: Geography and Ecosystem Analysis, Lund University, Lund, Sweden \\ $\dagger$ deceased on 29 June 2006
}

Received: 18 December 2008 - Published in Biogeosciences Discuss.: 8 April 2009

Revised: 19 March 2010 - Accepted: 24 April 2010 - Published: 17 May 2010

\begin{abstract}
Soil samples were collected in six South American countries in a total of 71 different 1 ha forest plots across the Amazon Basin as part of the RAINFOR project. They were analysed for total and exchangeable cations, $\mathrm{C}, \mathrm{N}, \mathrm{pH}$ with various $\mathrm{P}$ fractions also determined. Physical properties were also examined and an index of soil physical quality proposed. A diverse range of soils was found. For the western areas near the Andean cordillera and the southern and northern fringes, soils tend to be distributed among the lower pedogenetic levels, while the central and eastern areas of Amazonia have more intensely weathered soils. This gives rise to a large variation of soil chemical and physical properties across the Basin, with soil properties varying predictably along a gradient of pedogenic development. Nutrient pools generally increased slightly in concentration from the youngest to the intermediate aged soils after which a gradual decline was observed with the lowest values found in the most weathered soils. Soil physical properties were
\end{abstract}

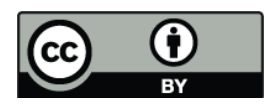

Correspondence to: C. A. Quesada (betoquesada@yahoo.com.br) strongly correlated with soil fertility, with favourable physical properties occurring in highly weathered and nutrient depleted soils and with the least weathered, more fertile soils having higher incidence of limiting physical properties. Soil phosphorus concentrations varied markedly in accordance with weathering extent and appear to exert an important influence on the nitrogen cycle of Amazon forest soils.

\section{Introduction}

During soil and ecosystem development nutrient levels change as a result of weathering. Essential elements for plant growth such as calcium, magnesium, potassium and phosphorus usually have their concentrations reduced, soil $\mathrm{pH}$ and clay activity tend to decrease and mineralogical composition changes (Smeck, 1973; Walker and Syers, 1976; Uehara and Gillman, 1981; Allen and Fanning, 1988). During this process, morphological characteristics of soils are also altered in response to the weathering forces of their environment. This ultimately results in associations between

Published by Copernicus Publications on behalf of the European Geosciences Union. 
great groups of soil classification and nutrient distribution in soils (Smeck, 1985). Soil phosphorus serves as an important indicator of such pedogenic processes (Smeck, 1973; Walker and Syers, 1976; Cross and Schlesinger, 1995) as total phosphorus decreases with soil weathering and with the remaining pool gradually transformed to more recalcitrant forms (Walker, 1964; Dahnke et al., 1964; Westin and de Brito, 1969; Smeck, 1973, 1985; Walker and Syers, 1976; Tiessen et al., 1984; Cross and Schlesinger, 1995; Crews et al., 1995; Johnson et al., 2003). On the other hand, nitrogen initially accumulates throughout pedogenesis as a result of atmospheric nitrogen deposition and microbial $\mathrm{N}_{2}$ fixation. This accumulation extends to a certain point after which nitrogen declines, being lost from the system and with remaining total soil nitrogen reaching some sort of stoichiometric equilibrium with soil phosphorus (Walker and Adams, 1958, 1959; Walker and Syers, 1976; Vitousek, 2004; Lambers et al., 2008).

Soils vary broadly across Amazonia with a large diversity of soil types, morphological characteristics and chemical and physical properties (Quesada et al., 2009a) and if meaningful relationships can be established between soil properties and FAO Reference Soil Groups (IUSS Working Group WRB, 2006) soil classification could be used for other practical purposes such as a source of information for global vegetation models, agricultural planning, and to improve our general knowledge of native, unexplored soils.

This paper reports on soil data from across the whole Amazon basin, both collected and analyzed in a methodologically consistent way. More than simply review the existing geographical patterns of soil fertility throughout the basin, this study aims to describe the inter-relationships and covariances among soil properties occurring in Amazonia, and determinate if such soil properties vary predictably along a pedogenesis gradient.

The results reported here are accompanied by two other papers in this series. First, the relationships between soil properties and soil genesis and taxonomy across Amazonia are discussed in Quesada et al. (2009a). Along with a review of the principal Amazonian soils, Quesada et al. (2009a) introduces the soil evolution framework used here to reflect the pedogenesis gradient. The last paper in the series, Quesada et al. (2009b) discusses the implications of the data reported here for vegetation productivity, structure and dynamics across Amazonia.

\section{Material and methods}

\subsection{Study area}

The soils of a total of 71 primary forest plots across the Amazon basin (Table 1) were sampled as part of this study. These included forests in Brazil, Venezuela, Bolivia, Colombia, Peru and Ecuador.
Soil sampling for all sites was carried out according to a standard protocol (see http://www.geog.leeds.ac.uk/projects/ rainfor/pages/manualstodownload.html). Due to often difficult access to the permanent sample plots and associated limitations in the number of samples for which it was practical to collect and return to field laboratories, a completely randomised sampling design across the sample plots was not possible. Rather, the sampling strategies adopted were adjusted to take into account landscape features that could imply spatial variability. For apparently homogeneous plots with flat topography five soil samples across the plot were usually taken to $2.0 \mathrm{~m}$ depth plus one soil pit with $1.5 \times 1.5 \mathrm{~m}$ width and $2.0 \mathrm{~m}$ depth, subsequently sampled from its bottom with an auger to a total depth of $4.0 \mathrm{~m}$. In areas with a higher level of spatial variability, the number of samples was increased accordingly, being as many as 12 cores per plot. In such plots samples were collected in such a way as to account for variations in topographic position, drainage capacity or clear changes in vegetation structure.

\subsection{Soil cores}

Within each soil core, samples were collected and all soil retained over the following depths: $0-0.05,0.05-0.10$, $0.10-0.20,0.20-0.30,0.30-0.50,0.50-1.00,1.00-1.50$ and $1.50-2.00 \mathrm{~m}$ using an undisturbed soil sampler (Eijkelkamp Agrisearch Equipment BV, Giesbeek, the Netherlands). For soil pits down to $2.0 \mathrm{~m}$ depth, samples were collected from the pit walls. All core samples were air dried as soon as practical with roots, detritus, small rocks and particles over $2 \mathrm{~mm}$ then removed in the laboratory. Samples, sieved at $2 \mathrm{~mm}$, were used in the laboratory for analysis. Throughout this paper only results for surface soils $(0-0.30 \mathrm{~m})$ were used.

\subsection{Soil pits}

Soil pits were situated at representative locations for the dominant soil and topographic positions, usually located a few metres outside the permanent sample plots in order to reduce potential disturbances to the trees growing there. Soil descriptions were first done following a standard soil description protocol (Guidelines for Soil Description; Jahn et al., 2006) with special attention paid to the following: measurement of total soil depth, depth to C horizon (where possible), horizon distribution, soil colour, distribution of rocks, presence or absence of concretions, ironstones or hardpans, redox-features, root amount and distribution, drainage capacity, soil hardness, soil structure accounting to aggregate distribution, aggregate type and aggregate stability, organic matter content, faunal activity, in situ particle size determination (including increments in clay content with depth), observations of easily weatherable minerals, distribution of soil porosity, in situ soil classification (supposed soil order), topographic location and finally, collection of three bulk density samples per sampling depth (as for the soil cores). 
Table 1. Study sites, their names, codes and World Reference Base soil classification. Geographic locations and climatic information are also shown.

\begin{tabular}{|c|c|c|c|c|c|c|c|c|}
\hline $\begin{array}{l}\text { Plot } \\
\text { Code }\end{array}$ & Plot Name & WRB Soil Classification & lat & long & temp & precip & Altitude & Country \\
\hline & & ACRISOLS & & & & & & \\
\hline ALF-01 & Alta Floresta, Cristalino Jungle Lodge, Plot 1 & Vetic Acrisol (Hyperdystric) & -9.601 & -55.937 & 25.87 & 2268 & 254 & Brazil \\
\hline CAX-01 & Caixuanã Plot 1 & Vetic Acrisol (Alumic, Hyperdystric) & -1.737 & -51.463 & 25.38 & 2856 & 41 & Brazil \\
\hline CAX-02 & Caixuanã Plot 2 & Vetic Acrisol (Alumic, Hyperdystric, Clayic) & -1.736 & -51.462 & 25.35 & 2856 & 46 & Brazil \\
\hline CAX-04 & Caixuanã Drought Experiment, Control Plot & Vetic Acrisol (Alumic, Hyperdystric) & -1.716 & -51.457 & 25.35 & 2856 & 31 & Brazil \\
\hline SCR-01 & San Carlos del Rio Negro, "Uhl Oxisol" & Vetic Acrisol (Ferric, Alumic, Hyperdystric, Arenic) & 1.933 & -67.022 & 26.06 & 3177 & 109 & Venezuela \\
\hline SCR-05 & San Carlos del Rio Negro, "Yevaro" & Vetic Acrisol (Alumic, Hyperdystric, Arenic) & 1.930 & -67.038 & 26.05 & 3177 & 111 & Venezuela \\
\hline \multirow[t]{2}{*}{ SUC-02 } & Sucusari, Plot B & Vetic Acrisol (Alumic, Hyperdystric, Clayic) & -3.251 & -72.904 & 26.22 & 2754 & 122 & Peru \\
\hline & & ALISOLS & & & & & & \\
\hline ALP-12 & Allpahuayo Plot A, "Non-Flooded" & Haplic Alisol (Alumic, Hyperdystric) & -3.948 & -73.436 & 26.25 & 2836 & 133 & Peru \\
\hline JAS-02 & Jatun Sacha, Plot 2 & Haplic Alisol (Hyperdystric, Clayic) & -1.068 & -77.615 & 23.47 & 4113 & 434 & Ecuador \\
\hline JAS-03 & Jatun Sacha, Plot 3 & Hyperalic Alisol (Alumic, Hyperdystric, Clayic) & -1.078 & -77.610 & 23.59 & 4113 & 410 & Ecuador \\
\hline JAS-04 & Jatun Sacha, Plot 4 & Haplic Alisol (Alumic, Hyperdystric) & -1.074 & -77.612 & 23.49 & 4113 & 430 & Ecuador \\
\hline TAM-01 & Tambopata Explorers Inn, Plot 0 & Haplic Alisol (Alumic, Hyperdystric, Siltic) & -12.844 & -69.288 & 25.61 & 2463 & 205 & Peru \\
\hline TAM- 02 & Tambopata Explorers Inn, Plot 1 & Haplic Alisol (Alumic, Hyperdystric, Siltic) & -12.835 & -69.286 & 25.58 & 2463 & 210 & Peru \\
\hline TIP-05 & Tiputini, Plot 5 & Hyperalic Alisol (Hyperdystric, Clayic) & -0.638 & -76.144 & 25.79 & 3328 & 237 & Ecuador \\
\hline YAN-01 & Yanamono, Plot A & Haplic Alisol (Alumic, Hyperdystric, Clayic) & -3.440 & -72.846 & 26.31 & 2754 & 104 & Peru \\
\hline TAM-06 & Tambopata Explorers Inn, Plot 4 & Haplic Alisol (Hyperdystric, Siltic) & -12.839 & -69.296 & 25.63 & 2463 & 200 & Peru \\
\hline ZAR-04 & El Zafire, "Altura" & Haplic Alisol (Alumic, Hyperdystric) & -4.007 & -69.901 & 25.49 & 2723 & 130 & Colombia \\
\hline \multirow[t]{2}{*}{ SUM-06 } & Sumaco volcano & $\begin{array}{l}\text { ANDOSOLS } \\
\text { Silandic Andosol (Hyperdystric, Siltic) }\end{array}$ & -1.750 & -77.630 & ? & ? & 1200 & Ecuador \\
\hline & & ARENOSOLS & & & & & & \\
\hline ALP-21 & Allpahuayo Plot B, "Sand" & Haplic Arenosol (Hyperdystric) & -3.953 & -73.437 & 26.20 & 2836 & 142 & Peru \\
\hline ALP-30 & Allpahuayo Plot C & Haplic Arenosol (Hyperdystric) & -3.954 & -73.426 & 26.19 & 2836 & 144 & Peru \\
\hline & & CAMBISOLS & & & & & & \\
\hline $\mathrm{HCC}-21$ & Huanchaca Dos, Plot 1 & Plinthic Acric Cambisol (Hyperdystric, Clayic) & -14.561 & -60.749 & 23.50 & 1348 & 721 & Bolivia \\
\hline BOG-01 & Bogi Plot A & Haplic Cambisol (Orthoeutric) & -0.699 & -76.482 & 25.68 & 3328 & 271 & Ecuador \\
\hline BOG-02 & Bogi Plot B & Haplic Cambisol (Orthoeutric) & -0.698 & -76.474 & 25.68 & 3328 & 270 & Ecuador \\
\hline CUZ-03 & Cuzco Amazônico, Plot 2E & Plinthic Cambisol (Orthoeutric) & -12.500 & -68.963 & 25.50 & 2190 & 190 & Peru \\
\hline JUR-01 & Rio Juruá & Vertic Cambisol (Hyperdystric, Clayic) & -8.884 & -72.790 & 25.89 & 2192 & 243 & Brazil \\
\hline ZAR-03 & El Zafire, "Tierra Firme" & Haplic Cambisol (Alumic, Hyperdystric, Clayic) & -3.995 & -69.900 & 25.59 & 2723 & 136 & Colombia \\
\hline TAM- 05 & Tambopata Explorers Inn, Plot 3 & Haplic Cambisol (Alumic, Hyperdystric, Clayic) & -12.830 & -69.271 & 25.53 & 2463 & 220 & Peru \\
\hline YAN-02 & Yanamono, Plot B & Stagnic Cambisol (Ferric, Hyperdystric, Siltic) & -3.434 & -72.843 & 26.31 & 2754 & 104 & Peru \\
\hline TAM- 07 & Tambopata Explorers Inn, Plot 6 & Haplic Cambisol (Alumic, Hyperdystric, Chromic) & -12.826 & -69.261 & 25.51 & 2463 & 225 & Peru \\
\hline RST-01 & Restauração, Plot 1 & Vertic Cambisol (Orthoeutric) & -9.044 & -72.267 & 25.91 & 2259 & 274 & Brazil \\
\hline CRP-01 & Cerro Pelao, plot 1 & Haplic Cambisol (Orthoeutric) & -14.538 & -61.500 & 25.02 & 1333 & 393 & Bolivia \\
\hline CRP-02 & Cerro Pelao, plot 2 & Haplic Cambisol (Orthoeutric) & -14.538 & -61.498 & 24.94 & 1333 & 396 & Bolivia \\
\hline ELD-12 & Eldorado km 91, Plots G1 \& G2 & Haplic Cambisol (Alumic, Hyperdystric) & 6.102 & -61.403 & 26.68 & 1976 & 201 & Venezuela \\
\hline & & FERRALSOLS & & & & & & \\
\hline SIN-01 & Sinop, Plot 1 & Geric Ferralsol (Ferric, Alumic, Hyperdystric, Arenic) & -11.411 & -55.325 & 25.84 & 2180 & 326 & Brazil \\
\hline BNT-04 & Bionte Plot 4 & Geric Ferralsol (Alumic, Hyperdystric, Clayic) & -2.628 & -60.153 & 26.95 & 2250 & 103 & Brazil \\
\hline CAX-06 & Caixuanã Eddy Covariance Tower & Geric Acric Ferralsol (Alumic, Hyperdystric, Clayic) & -1.716 & -51.457 & 25.35 & 2856 & 31 & Brazil \\
\hline CHO-01 & El Chore, Plot 1 & Geric Acric Ferralsol (Hyperdystric) & -14.386 & -61.148 & 26.18 & 1400 & 170 & Bolivia \\
\hline CPP-01 & Capitão Poço, Plot 1 & Geric Acric Ferralsol (Alumic, Hyperdystric) & -2.191 & -47.328 & $?$ & $?$ & 82 & Brazil \\
\hline LFB-01 & Los Fierros, Plot 1 & Geric Acric Ferralsol (Alumic, Hyperdystric) & -14.557 & -60.928 & 25.98 & 1348 & 225 & Bolivia \\
\hline LFB-02 & Los Fierros, Plot 2 & Geric Acric Ferralsol (Alumic, Hyperdystric) & -14.577 & -60.832 & 25.95 & 1348 & 230 & Bolivia \\
\hline MAN-12 & Manaus, Jacaranda, plateau \& slope & Geric Ferralsol (Alumic, Hyperdystric, Clayic) & -2.607 & -60.209 & 26.93 & 2250 & 106 & Brazil \\
\hline MBO-01 & Mocambo, Plot 1 & Haplic Ferralsol (Alumic, Hyperdystric) & -1.450 & -48.450 & 26.63 & 2924 & 24 & Brazil \\
\hline JRI-01 & Jari, EMBRAPA Control Plots & Gibbsic Geric Ferralsol (Alumic, Hyperdystric, Clayic, Xanthic) & -0.894 & -52.190 & 26.37 & 2393 & 127 & Brazil \\
\hline MAN-05 & Manaus, km 14 Eddy Covariance tower & Geric Acric Ferralsol (Alumic, Hyperdystric, Clayic) & -2.610 & -60.200 & 26.96 & 2250 & 100 & Brazil \\
\hline TAP-04 & Tapajós, LBA Tower & Gene Ferralsol (Alumic, Hyperdystric, Clayic, Xanthic) & -2.851 & -54.955 & 25.87 & 2009 & 197 & Brazil \\
\hline TAP- 123 & Tapajós, EMBRAPA Control Plots & Geric Ferralsol (Alumic, Hyperdystric, Clayic, Xanthic) & -3.310 & -54.942 & 25.87 & 2009.00 & 187 & Brazil \\
\hline & & FLUVISOLS & & & & & & \\
\hline JAS-05 & Jatun Sacha, Plot 5 & Haplic Fluvisol (Hyperdystric) & -1.062 & -77.622 & 23.67 & 4113 & 394 & Ecuador \\
\hline & & GLEYSOLS & & & & & & \\
\hline ALP-11 & Allpahuayo Plot A, "Flooded" & Haplic Gleysol (Alumic, Hyperdystric) & -3.949 & -73.434 & 26.28 & 2836 & 126 & Peru \\
\hline SUC-03 & Sucusari, Plot C & Haplic Gleysol (Alumic, Hyperdystric, Siltic) & -3.247 & -72.922 & 26.29 & 2754 & 107 & Peru \\
\hline TAM-04 & Tambopata Explorers Inn, Plot 2, swamp edge & Haplic Gleysol (Alumic, Siltic) & -12.836 & -69.278 & 25.61 & 2463 & 205 & Peru \\
\hline ZAR-02 & El Zafire, "Rebalse" & Haplic Gleysol (Alumic, Hyperdystric) & -4.002 & -69.904 & 25.49 & 2723 & 130 & Colombia \\
\hline TIP-03 & Tiputini, Plot 3 & Haplic Gleysol (Orthoeutric, Siltic) & -0.639 & -76.155 & 25.79 & 3328 & 248 & Ecuador \\
\hline & & LEPTOSOLS & & & & & & \\
\hline ELD-34 & Eldorado km 91, Plots G3 \& G4 & Hyperskeletic Leptosol (Orthodystric) & 6.083 & -61.406 & 25.84 & 1976 & 369 & Venezuela \\
\hline & & LIXISOLS & & & & & & \\
\hline RIO-12 & Rio Grande, Plots DA1 \& DA2 & Cutanic Lixisol (Ferric, Hypereutric) & 8.114 & -61.692 & 24.76 & 1225 & 270 & Venezuela \\
\hline & & NITISOLS & & & & & & \\
\hline HCC-22 & Huanchaca Dos, Plot 2 & Vetic Nitisol (Hypereutric, Rhodic) & -14.568 & -60.748 & 23.42 & 1348 & 736 & Bolivia \\
\hline & & PLINTHOSOLS & & & & & & \\
\hline AGP-01 & Agua Pudre, Plot E & Endostagnic Plinthosol (Alumic, Hyperdystric) & -3.741 & -70.306 & 25.84 & 2723 & 109 & Colombia \\
\hline AGP-02 & Agua Pudre, Plot U & Endostagnic Plinthosol (Alumic, Hyperdystric) & -3.741 & -70.303 & 25.86 & 2723 & 104 & Colombia \\
\hline DOI-01 & Dois Irmãos, Plot 1 & Haplic Plinthosol (Alumic, Orthodystric, Siltic) & -10.566 & -68.311 & 26.07 & 1875 & 198 & Brazil \\
\hline DOI-02 & Dois Irmãos, Plot 2 & Haplic Plinthosol (Alumic, Orthodystric, Siltic) & -10.556 & -68.301 & 26.02 & 1875 & 208 & Brazil \\
\hline LOR-01 & La Lorena, Plot E & Endostagnic Plinthosol (Alumic, Hyperdystric) & -3.056 & -69.991 & 25.92 & 2803 & 94 & Colombia \\
\hline LOR-02 & La Lorena, Plot U & Endostagnic Plinthosol (Alumic, Hyperdystric) & -3.058 & -69.993 & 25.92 & 2803 & 93 & Colombia \\
\hline ALP-22 & Allpahuayo Plot B, "Clay" & Haplic Plinthosol (Alumic, Hyperdystric) & -3.951 & -73.439 & 26.23 & 2836 & 137 & Peru \\
\hline SUC-01 & Sucusari, Plot A & Endostagnic Plinthosol (Alumic, Hyperdystric, Magnoferric, Clayic) & -3.252 & -72.907 & 26.21 & 2754 & 123 & Peru \\
\hline POR-01 & Porongaba, Plot 1 & Haplic Plinthosol (Alumic, Hyperdystric) & -10.818 & -68.776 & 25.45 & 1905 & 275 & Brazil \\
\hline POR-02 & Porongaba, Plot 2 & Haplic Plinthosol (Alumic, Hyperdystric) & -10.800 & -68.773 & 25.48 & 1905 & 269 & Brazil \\
\hline & & PODZOLS & & & & & & \\
\hline ZAR-01 & El Zafire, "Varillal" & Ortseinc Podzol (Oxyaquic) & -4.007 & -69.906 & 25.51 & 2723 & 127 & Colombia \\
\hline MAN-03 & Manaus, Jacaranda, campinarana & Umbric Podzol (Oxyaquic) & -2.609 & -60.214 & 27.00 & 2250 & 92 & Brazil \\
\hline MAN-04 & Manaus, Jacaranda, baixio & Umbric Podzol (Oxyaquic) & -2.609 & -60.216 & 26.96 & 2250 & 100 & Brazil \\
\hline SCR-04 & San Carlos del Rio Negro, "Tall caatinga" & Umbric Podzol (Oxyaquic) & 1.927 & -67.036 & 26.06 & 3177 & 110 & Venezuela \\
\hline & & UMBRISOLS & & & & & & \\
\hline LSL-01 & Las Londras, Plot 1 & Endogleyic Umbrisol (Alumic, Hyperdystric) & -14.408 & -61.140 & 26.11 & 1400 & 185 & Bolivia \\
\hline LSL-02 & Las Londras, Plot 2 & Endogleyic Umbrisol (Alumic, Hyperdystric) & -14.408 & -61.138 & 26.12 & 1400 & 182 & Bolivia \\
\hline
\end{tabular}




\subsection{Soil classification}

Soils from this study were classified using the recently released World Reference Base for Soil Resources (IUSS Working Group WRB, 2006). This soil classification is based on soil properties of diagnostic horizons that can be measured, as well as on morphological characteristics that can be observed in the field. It takes into account soil formation processes but is not directly based on them.

Classification is made at two complementary levels. The first gives the nomenclature for Reference Soil Group (RSG), which represents the great order level. The next level of classification contributes a combination of prefix and suffix qualifiers that are added to the RSG name. This allows precise characterization and qualification of individual soils, with the advantage of having well defined Reference Soil Groups for some important tropical soil groups which are only defined as great groups or subgroups in the US Soil taxonomy (Quesada et al., 2009a).

\subsection{Laboratory methods}

Soil samples were analysed at three different institutions depending on sampling location: Max-Planck Institute fuer Biogeochemie (MPI), Jena, Germany; Instituto Venezuelano de Investigaciones Cientificas (IVIC), Caracas, Venezuela; or Instituto Nacional de Pesquisas da Amazonia (INPA), Manaus, Brazil. All laboratories were under inter-calibration exercises and used the same methodologies and sample standards. For the Venezuelan soils, only cation exchange capacity and resin extractable phosphorus were measured at IVIC, with soil carbon and nitrogen content being determined at MPI and soil texture analysed in INPA. Soil phosphorus pools, total soil $\mathrm{P}$ and total reserve bases were all analysed in INPA and Leeds laboratories (University of Leeds, School of Geography). Soil $\delta^{15} \mathrm{~N}$ of the Brazilian, Colombian and Venezuelan samples were analysed at the Centro de Energia Nuclear na Agricultura (CENA) in Piracicaba (Brazil) with the MPI analysing soils from Bolivia, Ecuador and Peru. Again, both laboratories were under inter-calibration exercises and used the same methodologies and sample standards.

\subsubsection{Soil pH}

Soil $\mathrm{pH}$ was determined as $1: 2.5, \mathrm{H}_{2} \mathrm{O}$ extracted with $10 \mathrm{~g}$ of fine earth shaken with $25 \mathrm{ml} \mathrm{H}_{2} \mathrm{O}$ for $1 \mathrm{~h}$ on a circular shaker, rested for $1 \mathrm{~h}$ and with the $\mathrm{pH}$ of supernatant then read using an automatic probe. With the purpose of aiding the soil classifications, soil $\mathrm{pH}$ was also determined in $1 \mathrm{M} \mathrm{KCl}$ solution in selected samples.

\subsubsection{Exchangeable cations}

Two different routines were used for the estimation of exchangeable cations, each appropriate to a specific use.
Exchangeable cations extracted with the objective of studying the effects of soil nutrient availability on vegetation were performed at soil $\mathrm{pH}$. This is because tropical soils often contain significant amounts of variable charge clays, therefore the use of $\mathrm{pH}$ buffered solutions, such as the standard $\mathrm{NH}_{4} \mathrm{OAc}$ method at $\mathrm{pH} 7$, artificially creates additional charges on soil surface, resulting in inaccurate measurements of plant exchangeable cations (Uehara and Gillman, 1981). However, $\mathrm{pH}$ buffered solutions are required for soil classification purposes; with the view to standardize activity and exchangeable properties of clays. Therefore, methods for extracting exchangeable cations were as follows.

At soil pH: Exchangeable $\mathrm{Ca}, \mathrm{Mg}, \mathrm{K}, \mathrm{Na}$ and $\mathrm{Al}$ were determined by the silver thiourea method (Ag-TU; Pleysier and Juo, 1980). This is a rapid and convenient method that allows a one-step centrifuge extraction with $0.01 \mathrm{M} \mathrm{Ag-TU}$ solution through which complete cation exchange is achieved. Additional advantages of this method include the low molarity of the extractant, its high effectiveness over a large range of soil $\mathrm{pH}$, particularly important in this work, and an excellent comparison with other methods such as $\mathrm{NH}_{4} \mathrm{Ac}$ and $1 \mathrm{M} \mathrm{KCl}$ (Pleysier and Juo, 1980).

Samples of approximately $20 \mathrm{~g}$ of fine earth were crushed through a $0.5 \mathrm{~mm}$ sieve and $5 \mathrm{~g}$ of sieved samples subsequently weighted into a $50 \mathrm{ml}$ centrifuge tube including two blanks and at least one control sample per sample run (typically 50 samples). Each sample run was checked and standardised with extracts from the Montana SRM 2710 soil standard reference (National Institute of Standards of Technology, Gaithersburg, MD, USA).

Firstly, $40 \mathrm{ml}$ of Ag-TU $0.01 \mathrm{M}$ was added into each centrifuge tube and shaken for four hours in a reciprocating shaking machine, after which samples were centrifuged for $15 \mathrm{~min}$ at $3000 \mathrm{rpm}$ and filtered through Whatman 43 filters. Analyses of the filtered extracts were then done by AAS at INPA and IVIC and by ICP-OES in Jena. ICP-OES has the advantage that it does not suffer any influences by refractory components for $\mathrm{Ca}, \mathrm{Mg}$ and $\mathrm{Al}$ readings but for AAS determinations at INPA and IVIC, sample dilutions for $\mathrm{Ca}, \mathrm{Mg}$ and $\mathrm{Al}$ were done using a $0.55 \%$ lanthanum suppressant solution. Similarly $\mathrm{K}$ and $\mathrm{Na}$ also had their detection improved by addition of $0.2 \% \mathrm{CsCl}$.

At pH 7: Cation Exchange Capacity (CEC) and exchangeable bases were measured by ammonium acetate $\mathrm{pH} 7$ $\left(\mathrm{NH}_{4} \mathrm{Ac} \mathrm{pH} 7\right.$; Van Reeuwijk, 2002), with the objective of referencing standard soil classification. CEC values were adjusted for organic matter content and expressed on clay basis. Exchangeable Al was analysed using the silver thiourea method (Pleysier and Juo, 1980), as well as by $1 \mathrm{M} \mathrm{KCl} \mathrm{ex-}$ traction for selected Brazilian samples. Thus, all collected samples were analysed using the Ag-TU method, while a large subset of the samples was analysed by both methods. With the purpose of using $\mathrm{Al}$ values in the standard soil classification system, $\mathrm{Al}$ in $\mathrm{Ag}$-TU extracts were adjusted to $1 \mathrm{M} \mathrm{KCl} \mathrm{levels} \mathrm{using} \mathrm{an} \mathrm{equation} \mathrm{derived} \mathrm{by} \mathrm{the} \mathrm{means} \mathrm{of}$ 
a non parametric regression. More details and comparisons between the methods are giving in Quesada et al. (2009a).

\subsubsection{Soil phosphorus}

Initially all samples collected during this study were analysed for extractable phosphorus using the anion exchange resin method (Nuernberg et al., 1998). This method has been usually considered to give the most reliable indication of immediate plant available phosphorus (Kuo, 1996). It consists of shaking an activated resin strip in $40 \mathrm{ml}$ of $\mathrm{H}_{2} \mathrm{O}$ together with $5 \mathrm{~g}$ of soil for $18 \mathrm{~h}$ in a reciprocating shaker, after which the resin strip is removed, gently cleaned with as little $\mathrm{H}_{2} \mathrm{O}$ as possible to remove any remaining soil particles and then added to a second centrifuge tube containing $25 \mathrm{ml}$ of $\mathrm{H}_{2} \mathrm{SO}_{4}$ $0.1 \mathrm{M}$ and shaken again for $15 \mathrm{~min}$. The extract was then determined by molybdenum blue colour development as described by Olsen and Sommers (1982) in the INPA and IVIC laboratories or by ICP-OES in Jena. Details regarding resin strips activation, standard series and solution preparation are provided in detail in Nuernberg et al. (1998). However, initial analysis of soil phosphorus results following the resin method (as in Nuernberg et al., 1998), did not seem meaningful at all when compared to vegetation traits such as leaf $\mathrm{P}$ concentrations or forest growth.

A more comprehensive assessment of available phosphorus was thus adopted (Hedley et al., 1982). The method consists of a sequential extraction with reagents of increasing strength. The first step being resin extractable $\mathrm{P}$, followed by $0.5 \mathrm{M} \mathrm{NaHCO}_{3}, 0.1 \mathrm{M} \mathrm{NaOH}$ and $1 \mathrm{M} \mathrm{HCl}$. Total phosphorus was also determined by acid digestion using concentrate sulphuric acid followed by $\mathrm{H}_{2} \mathrm{O}_{2}$ as described in Tiessen and Moir (1993). The extraction results in eight different fractions named as resin P, bicarbonate inorganic, bicarbonate organic, sodium hydroxide inorganic, sodium hydroxide organic, hydrochloric acid, residual and total phosphorus; the residual fraction being determined here as the difference between the total pool and the sum of all other labile fractions.

Total phosphorus was determined on a replicate soil sample in order to avoid additional complications which could arise from transferring the remaining soil after the fractionation to the digestion tubes. Transfer of the residual soil incurred an occasional loss of the sample and the necessity to repeat the whole fractionation process, which makes it unfeasible given the large amount of samples analysed in this study. Laboratory tests were thus conducted to determine if the use of another sample for total P determinations would result in values comparable to those adding up of all $\mathrm{P}$ fractions plus the digestion of the residual soil. The method proved to be convenient and reliable, with an almost perfect agreement between total $\mathrm{P}$ in a replicate sample and the sum of all fractions $\left(R^{2}=0.99\right)$.

As the phosphorus fractionation technique requires intensive laboratory work, compound samples were made by amalgamating the upper soil depths to $0.3 \mathrm{~m}$. Therefore, each study site had four compound samples analysed for phosphorus fractionations, divided in the depths of $0-0.05 \mathrm{~m}, 0.05-$ $0.1 \mathrm{~m}, 0.1-0.2 \mathrm{~m}$ and $0.2-0.3 \mathrm{~m}$.

After the preparation of the compound samples, they were homogenized and duplicates weighted into $50 \mathrm{ml}$ centrifuge tubes. The first step in the fractionation scheme was then to add $30 \mathrm{ml}$ of ultra pure deionised water to each tube along with two pre-activated resin strips. Samples were then shaken in a reciprocating shaker for $16 \mathrm{~h}$, had the resin strips gently removed and cleaned with a little deionised water with any residual soil placed back into the tube. Resin strips were then placed in another $50 \mathrm{ml}$ vial with $20 \mathrm{ml}$ of $0.5 \mathrm{M} \mathrm{HCl}$ and reserved to be shaken overnight along with other samples from the second step of the fractionation scheme.

The remaining water and soil was then centrifuged at $18000 \mathrm{rpm}$ for $15 \mathrm{~min}$ in a cooled centrifuge at $0^{\circ} \mathrm{C}$ (not available in Leeds). The supernatant was then filtered through a Millipore filter $0.45 \mu$ and discarded. Any residue in the filter was then transferred back into the initial centrifuge tube using a little bit of the subsequent extracting solution, in this case $0.5 \mathrm{MNa}$-bicarbonate with $\mathrm{pH}$ adjusted to 8.5. Once all soil particles held in the filter were placed back into the tube, $30 \mathrm{ml}$ of $0.5 \mathrm{M} \mathrm{Na}$-bicarbonate was added and samples shaken overnight for $16 \mathrm{~h}$ and then filtered. This procedure was repeated for $\mathrm{NaOH}$ and $\mathrm{HCl}$ solutions, with all extracts kept for subsequent analysis. Resin and $\mathrm{HCl}$ fractions yield inorganic phosphorus with the bicarbonate and hydroxide fractions extracting both organic and inorganic P. Inorganic phosphorus was separated in the Na-bicarbonate and Na-hydroxide fractions by acid precipitation of organic matter with organic fractions then calculated as the difference between the inorganic fraction and the total phosphorus in these extracts as analysed by wet oxidation with sulphuric acid and ammonium persulphate to convert organic $\mathrm{P}$ to inorganic form (Tiessen and Moir, 1993). All phosphorus extracts, including those of total $\mathrm{P}$ extractions, had their $\mathrm{pH}$ adjusted to 4.5 using 4-nitrophenol as colour indicator and $0.25 \mathrm{M} \mathrm{H}_{2} \mathrm{SO}_{4}$ and $4 \mathrm{M} \mathrm{NaOH}$ as adjusting solutions with analysis of final extracts was undertaken following the blue colour development method of Murphy and Riley (1962) read in a spectrophotometer at $712 \mathrm{~nm}$ wave length.

The "readily available pool" is estimated by the adding up of resin and bicarbonate fractions (organic and inorganic), whith the "total extractable P" taken here to consist of the sum of both organic and inorganic phosphorus from the resin, bicarbonate, hydroxide and hydrochloric acid steps.

Comparisons between resin P (as in Nuernberg et al., 1998) and the resin P step in Hedley fractionations (Hedley et al., 1982) further suggested that the Nuernberg resin method was not an informative procedure for available $\mathrm{P}$ determination for the studied soils. Therefore, Nuernberg resin P will not be considered further in this paper. 


\subsubsection{Chemical weathering index and total element concentrations}

To investigate the weathering levels of soils within the dataset, the weathering index Total Reserve Bases, $\Sigma_{\mathrm{RB}}$, was calculated. This index is based on total cation concentration in the soil and is considered to give a chemical estimation of weatherable minerals (Delvaux et al., 1989). Soil samples were extracted for total elemental concentrations ( $\mathrm{Ca}, \mathrm{Mg}, \mathrm{K}$ and $\mathrm{Na}$ ) by strong acid digestion using concentrate sulphuric acid followed by $\mathrm{H}_{2} \mathrm{O}_{2}$. Concentrations were determined by ICP-OES with $\Sigma_{\mathrm{RB}}$ equal to $[\mathrm{Ca}]_{\mathrm{T}}+[\mathrm{Mg}]_{\mathrm{T}}+[\mathrm{K}]_{\mathrm{T}}+[\mathrm{Na}]_{\mathrm{T}}$, where $[\mathrm{X}]_{\mathrm{T}}$ represents the total concentration of each element in $\mathrm{mmol}_{\mathrm{c}} \mathrm{kg}^{-1}$ soil.

\subsubsection{Carbon and nitrogen}

Soil samples were milled to less than $50 \mu \mathrm{m}$ and subsequently weighed into tin foils, starting with $5 \mathrm{mg}$ in the surface samples and increasing to approximately $1 \mathrm{mg}$ for each soil depth increment. Samples were placed in an automatic sampler and transferred to a combustion tube for analysis using an automated elemental analyser (Pella, 1990; Nelson and Sommers, 1996).

\subsubsection{Nitrogen isotopes}

Analysis of $\delta^{15} \mathrm{~N}$ was with a high precision isotope ratio mass spectrometer coupled with an elemental analyser and sharing common methods and reference samples. As there is significant variation with depth in both concentration and stable isotopic composition of nitrogen in soils, data from each site was grouped by soil depth to $0.3 \mathrm{~m}$ and then [N]-weighted averages taken.

\subsubsection{Particle size analysis}

Particle size analyses were undertaken using the Boyoucos method (Gee and Bauder, 1986). As detailed below, $50 \mathrm{~g}$ of fine earth was first treated with physical and chemical dispersants and then separated into sand (particle sizes between 0.05 and $2 \mathrm{~mm}$ ), silt (particle sizes between $0.002 \mathrm{~mm}$ and $0.05 \mathrm{~mm}$ ) and clay contents (particle sizes $<0.002 \mathrm{~mm}$ ) by the means of a series of hygrometer readings in a settling soil solution over time.

Samples were first left $18 \mathrm{~h}$ with approximately $200 \mathrm{ml}$ of water plus $20 \mathrm{ml}$ of a chemical dispersant solution (see below) after which they agitated in a commercial milkshake maker (provided through Eijkelkamp Agrisearch Equipment BV, Giesbeek, the Netherlands) for $15 \mathrm{~min}$ at $5000 \mathrm{rpm}$. The resultant solution of soil, water and dispersant was then passed through a $212 \mu \mathrm{m}$ sieve which retained sand fraction. The remaining solution containing clay, silt and dispersant was then added to a $1 \mathrm{~L}$ measuring cylinder, made up to $1000 \mathrm{ml}$ total volume and agitated vigorously with a rod for
$1 \mathrm{~min}$, subsequently being left to rest and settle for $22 \mathrm{~h}$ over which a series of readings were undertaken.

The influence of the dispersant solution on the particle size readings was removed from the calculations using data from a blank sample containing the same proportion of dispersant as used for the analysis. Inter-calibration exercises done using the pipette method (Gee and Bauder, 1986) showed the resting time for clay determinations to be accurately made with a hygrometer was at least $22 \mathrm{~h}$. During this procedure, we noticed that the accuracy of results for different soils depended on the type of chemical dispersant. Ferralsols showed better dispersion with $\mathrm{NaOH} 6 \%$, while soils rich in $\mathrm{Ca}$ responded better to Na-pyrophosphate 5\%. Nahexametaphosphate $6 \%$ also gave reliable results for $\mathrm{Ca}$ rich soils. Another important detail is that a high level of organic matter can have a strong influence over particle size analysis. In this study, samples with organic matter concentration higher than $2 \%$ were thus treated prior to dispersion using $10 \mathrm{ml}$ of concentrated $\mathrm{H}_{2} \mathrm{O}_{2}$ stirred on a hot plate to $50^{\circ} \mathrm{C}$ until complete destruction of organic matter was observed (usually overnight). Usual measurement times for hydrometer readings were $30 \mathrm{~s}, 1 \mathrm{~min}, 2 \mathrm{~h}$ and $22 \mathrm{~h}$.

With the purpose of aiding soil classifications (Quesada et al., 2009a) water dispersible clay determinations were also undertaken for selected horizons. The method used for the clay determination was the pipette method, without the addition of chemical dispersant.

\subsubsection{Bulk density}

Samples for bulk density determinations were made for pit samples using specially designed container-rings of known volume (Eijkelkamp Agrisearch Equipment BV, Giesbeek, the Netherlands) and subsequently oven dried at $105^{\circ} \mathrm{C}$ until constant weight, cooled to room temperature in a sealed desiccant before final weight determinations were made.

\subsection{Soil physical constraints}

A score table (Table 2) for quantifying the magnitude of limiting soil physical conditions was developed to allow the conversion of soil descriptions into a more useful semiquantitative framework that could be used in statistical analysis. The score table was based on physical conditions that could be harmful for tropical forest trees and consequently increase forest disturbance. Those parameters are well known to influence tree growth and survival and are subject to several indexes of soil quality around the world, as the US Land Capability Classification system (US Soil Survey Staff), the Brazilian Land Capability System (Ramalho Filho and Beek, 1995), the Fertility Capability Classification System (Sanchez et al., 2003) and The Storie Index Rating (Storie and Wieslander, 1948).

Although parameters such as soil depth and topography were directly measurable, due to their necessary descriptive 
Table 2. Score table for soil physical constraints.

\begin{tabular}{ll}
\hline Soil physical constraints rating categories & Score \\
\hline Effective soil depth (soil depth, hardpans) & \\
Shallow soils (less than $20 \mathrm{~cm}$ ) & 3 \\
Less shallow ( 20 to $50 \mathrm{~cm}$ ) & 3 \\
Hardpan or rock that allows vertical root growth; other soils between 50 & 2 \\
and $100 \mathrm{~cm}$ deep. & 1 \\
Hardpan, rocks or C horizon $\geq 100 \mathrm{~cm}$ deep & 0 \\
Deep soils $\geq 150 \mathrm{~cm}$ & \\
\hline Soil structure & 4 \\
Very dense, very hard, very compact, without aggregation, root restrictive & 3 \\
Dense, compact, little aggregation, lower root restriction & 2 \\
Hard, medium to high density and/or with weak or block like structure & 1 \\
Loose sand, slightly dense; well aggregated in sub angular blocks, discontinuous pans & 0 \\
Good aggregation, friable, low density & \\
\hline Topography & 4 \\
Very steep $>45^{\circ}$ & 3 \\
Steep $20^{\circ}$ to $44^{\circ}$ & 2 \\
Gentle undulating $8^{\circ}$ to $19^{\circ}$ & 1 \\
Gentle sloping $1^{\circ}$ to $8^{\circ}$ & 0 \\
Flat $0^{\circ}$ & 0 \\
\hline Anoxic conditions & \\
Constantly flooded; patches of stagnated water & 2 \\
Seasonally flooded; soils with high clay content and very low porosity and/or & 4 \\
dominated by plinthite & \\
Deep saturated zone (maximum high of saturation $50 \mathrm{~cm}$ deep); redox features & \\
Deep saturated zone (maximum high of saturation $>100 \mathrm{~cm}$ deep); deep redox features & \\
Unsaturated conditions & \\
\hline
\end{tabular}

nature others such as soil structure and average long-term anoxic conditions were not. Here soil structure was considered as an association of soil properties, the first group consisting of the type of aggregate (granular; sub angular blocks; blocks; no aggregation), the quantity of aggregates observed (well; some; few; very few; none), and the stability of the aggregates (very stable; stable; weak; none). The second group was soil hardness (friable; slightly hard/compact; hard/compact; very hard/compact) and the final factor, the soil bulk density (very low $<1.0 \mathrm{~g} \mathrm{~cm}^{-3}$; low 1.0 to $1.2 \mathrm{~g} \mathrm{~cm}^{-3}$; medium 1.2 to $1.4 \mathrm{~g} \mathrm{~cm}^{-3}$; high $>1.4 \mathrm{~g} \mathrm{~cm}^{-3}$ ). The $\mathrm{B}$ horizon was taken as the control section for the structure scores (or $\mathrm{C}$ in soils without $\mathrm{B}$ horizon). The scoring of soil structure then followed the experience and the viewpoint of the person making the rating, taking into account that a friable, low density and well aggregated soil as well as a hard, massive, compact, dense soil, and without aggregation, will be the extremes of the structural range.

Another consideration was that soils with deficient structure frequently have roots only in patches of good aggregation and if this was the situation the assessor scored this soil as root restrictive. Ferralsols were considered as the standard for structural quality as they are highly weathered with a low density, high porosity, also being friable and with good aggregation even deep in the B horizon. In addition, the hydrologic properties of these soils are favourable and largely independent of clay content (Driessen et al., 2001; Sanchez, 1987; Quesada et al., 2009a).

Anoxic conditions were sometimes clearly identifiable where stagnating water was lying over the soil or when soil saturation was evident. But it may also be more complex to identify. This work has thus considered three different anoxic conditions: permanently flooded, seasonally flooded and soil redox features only.

All physical constraints were considered jointly to allow for the interaction among characteristics (Muchena, 1979) with a simple index of physical properties quantified adding up scores from each factor to give a soil physical quality index ( $\Pi)$ using the equation below:

$\Pi=\mathrm{D}+\mathrm{S}+\mathrm{T}+\mathrm{A}$,

With D, S, T and A being the scores for depth, structure, topography and anoxia respectively. 


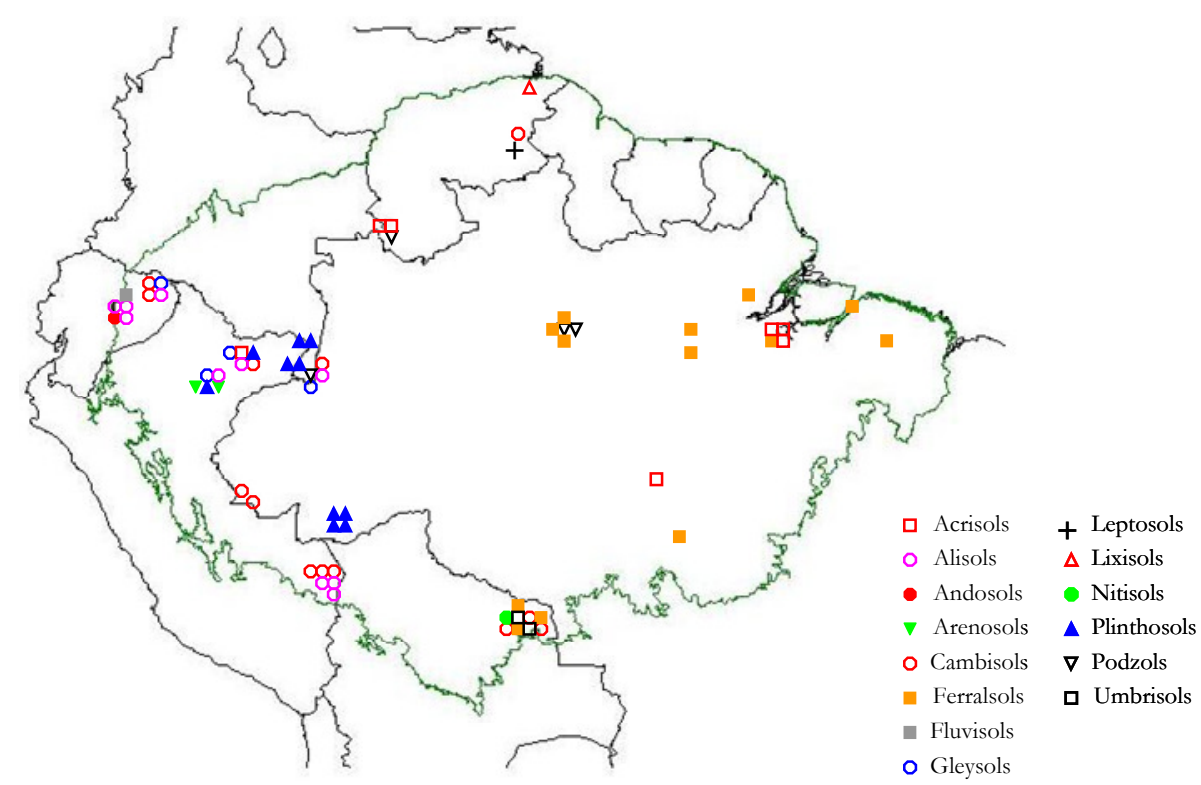

Fig. 1. Distribution of identified soil types across Amazonia.

With its dependence on subjective interpretations, there must have been some bias in the soil scores. Although its magnitude should have been small, mainly resulting from misplacing a score in an adjacent level, (for instance, giving of a score of 3 instead of 4) in order to assess the likely magnitude of any "observer effect", assessments were undertaken independently by C. A. Quesada, M. G. Hodnett and R. Herrera with all three assessors using the same soil descriptions. This comparative study, the results of which are outlined in the Supplementary Information: http://www.biogeosciences. net/7/1515/2010/bg-7-1515-2010-supplement.pdf, yielded a Kendall's coefficient of concordance of $W=0.92$ (Lemon and Fellows, 2007) demonstrating a high degree of agreement for the three assessors who also clearly did not differ significantly in their rankings for the soils analysed $(\mathrm{P}<0.001)$. Thus, assessor dependent variation in $\Pi$ should not have had any appreciable influence on the results shown here (Siegel and Castellan, 1988) these being the $\Pi$ scores of C. A. Quesada only.

\subsection{Calculations}

In this study soil effective cation exchange capacity, $I_{\mathrm{E}}$, was calculated, ignoring any exchangeable $\left[\mathrm{H}^{+}\right]$, as

$I_{\mathrm{E}}=[\mathrm{Ca}]_{\mathrm{E}}+[\mathrm{Mg}]_{\mathrm{E}}+[\mathrm{K}]_{\mathrm{E}}+[\mathrm{Na}]_{\mathrm{E}}+[\mathrm{Al}]_{\mathrm{E}}$,

where $[\mathrm{X}]_{\mathrm{E}}$ represents the exchangeable concentration of each element in $\mathrm{mmol}_{\mathrm{c}} \mathrm{kg}^{-1}$ soil. Sum of bases, $\Sigma_{\mathrm{B}}$ and aluminium saturation, $S_{\mathrm{Al}}$ were also calculated:

$\Sigma_{\mathrm{B}}=[\mathrm{Ca}]+[\mathrm{Mg}]+[\mathrm{K}]+[\mathrm{Na}]$,

and

$S_{\mathrm{Al}}=[\mathrm{Al}] /\left(\Sigma_{\mathrm{B}}+[\mathrm{Al}]\right)$,

\subsection{Data availability}

All soil data used in this study is available in the Supplementary Information: http://www.biogeosciences.net/ 7/1515/2010/bg-7-1515-2010-supplement.pdf. Electronic datasheets can be made available under request.

\section{Results}

\subsection{Distribution of soil types, natural fertility and physical properties across Amazonia}

A diverse range of soils was found. For the western areas near the Andean cordillera and the southern and northern fringes, soils tend to be distributed among the lower pedogenetic levels (for example Cambisols), while the central and eastern areas of Amazonia have more intensely weathered soils such as Acrisols and Ferralsols (Fig. 1).

Associated with wide variability in soil type was a broad variation of soil chemical and physical properties and Fig. 2 shows the distribution of the soil fertility indicators sum of bases $\left(\Sigma_{\mathrm{B}}\right.$; Fig. 2a) and total phosphorus $\left(\mathrm{P}_{\mathrm{T}}\right.$, Fig. $\left.2 \mathrm{~b}\right)$ across the basin. Comparison with Fig. 1 shows, as expected, that favourable fertility seems to be mostly related to soils with relatively low pedogenetic level near the Andes with unfavourable fertility conditions usually associated with soils at an advanced stage of weathering (i.e. Ferralsols) or a low parent material fertility in soils of low pedogenetic level (i.e. Dystrophic Cambisols).

Soil physical properties might also be expected to be related to soil age, defined here as pedogenic status (i.e. Cambisols are considered young and Ferralsols to be old) and thus 

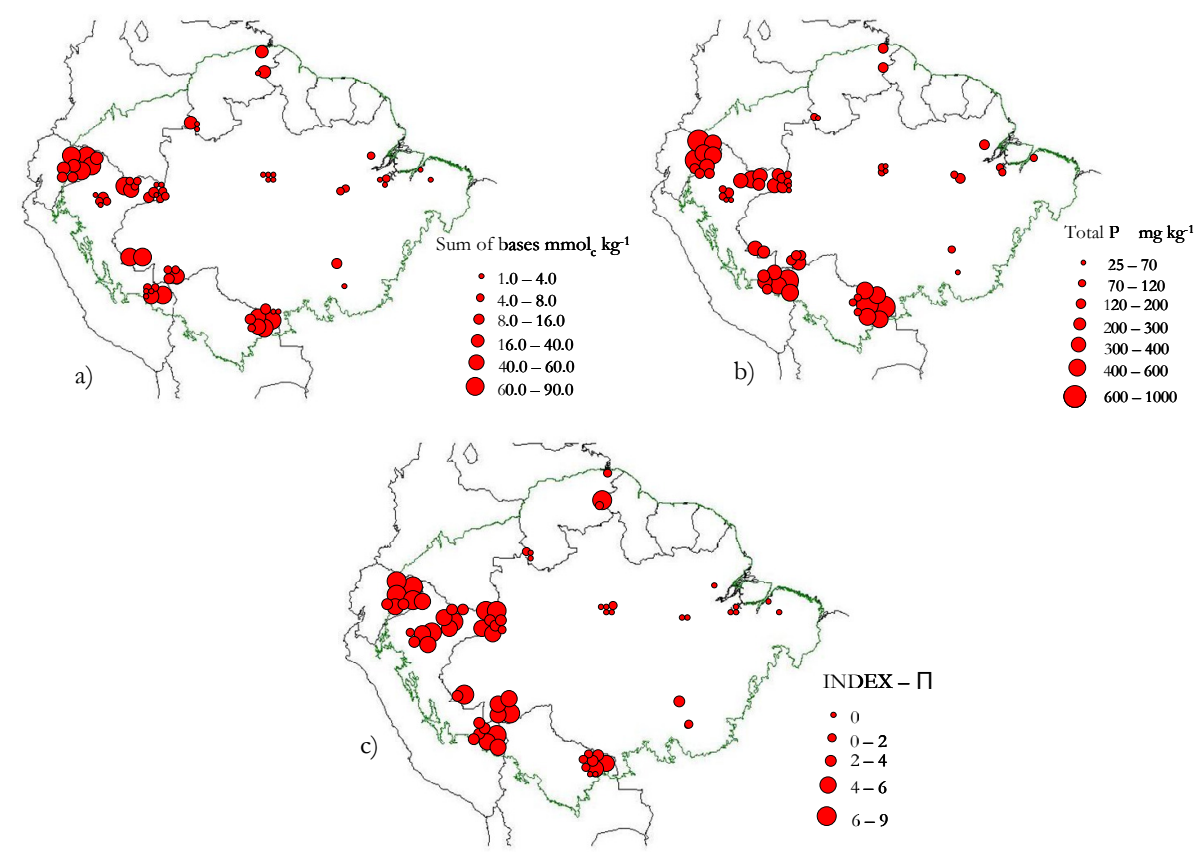

Fig. 2. Distribution of chemical and physical properties of soils across Amazonia. (a) sum of bases; (b) total phosphorus and (c) index for soil physical properties (П). Size of circles represent concentration differences among sites, see legend for details.

to soil forming factors such as topography and natural erosion as well as to landscape position and drainage. The index of physical properties described in Sect. 2.6 has thus been mapped in Fig. 2c. This, along with the soil type distribution in Fig. 1, shows that most of the well developed soils, notably the Ferralsols group, have low $\Pi$, suggesting an almost total lack of limiting physical properties. Likewise, soil groups occupying the lower pedogenic levels, usually located on the margins of the Basin, usually show limiting physical conditions to some degree.

\subsection{Distribution of nutrients across the soil age gradient}

As expected, chemical properties of Amazonian soils were found to change predictably with pedogenic development and Fig. 3 shows observed ranges of nutrient concentration plotted against soil type, for both Reference Soil Groups (RSG) and lower classification levels, which have been ordered according to increasing substrate age as in Quesada et al. (2009a). A key for lower classification levels is found in Table 3. A consistent trend was found across the soil development gradient, with $\mathrm{P}_{\mathrm{T}}, I_{\mathrm{E}}, \Sigma_{\mathrm{B}}$ and $[\mathrm{Al}]_{\mathrm{E}}$ all tending to increase slightly from the youngest to the intermediate aged soils, after which a gradual decline occurs with the lowest values found in the most weathered soils. A wide range of variation in $\mathrm{P}_{\mathrm{T}}$ was found among the different soil types, with very high levels, in Fluvisols, Andosols and Cambisols but also with relatively large pools in most intermediate aged soils such as Alisols and Plinthosols. Phosphorus levels on
Table 3. Details for WRB lower classification levels within the dataset.

\begin{tabular}{lcll}
\hline RSG & Subgroup & Prefixes & Suffixes \\
\hline Gleysols & 1 & Haplic & Hyperdystric Alumic \\
Gleysols & 2 & Haplic & Orthoeutric \\
Cambisols & 1 & $\begin{array}{l}\text { Plinthic, } \\
\text { Vertic or Haplic }\end{array}$ & Orthoeutric \\
& & Stagnic or Vetic & Hyperdystric \\
Cambisols & 2 & Haplic & Hyperdystric Alumic \\
Cambisols & 3 & Haplic & Hyperdystric \\
Alisols & 1 & Hyperalic & Hyperdystric \\
Alisols & 2 & Haplic & Hyperdystric Alumic \\
Alisols & 3 & Endostagnic & Hyperdystric Alumic \\
Plinthosols & 1 & Haplic & Hyperdystric Alumic; \\
Plinthosols & 2 & Orthodystric Alumic \\
& & Vetic & Hyperdystric \\
Acrisols & 1 & Vetic & Hyperdystric Alumic \\
Acrisols & 2 & Geric & Hyperdystric Alumic \\
Ferralsols & 1 & Geric Acric & Hyperdystric; \\
Ferralsols & 2 & & Hyperdystric Alumic \\
& & &
\end{tabular}

Ferralsols and Acrisols were lower, but still on average four times higher than in those of Podzols and Arenosols. Within group variation was considerable in Cambisols and Gleysols, but was minor in Alisols and Plinthosols and indistinguishable in Acrisols and Ferralsols. Changes in $I_{\mathrm{E}}$ along the age gradient (Fig. 3b) were very similar to that of $\mathrm{P}_{\mathrm{T}}$ but within RSG variation was usually narrower. This was in contrast to 

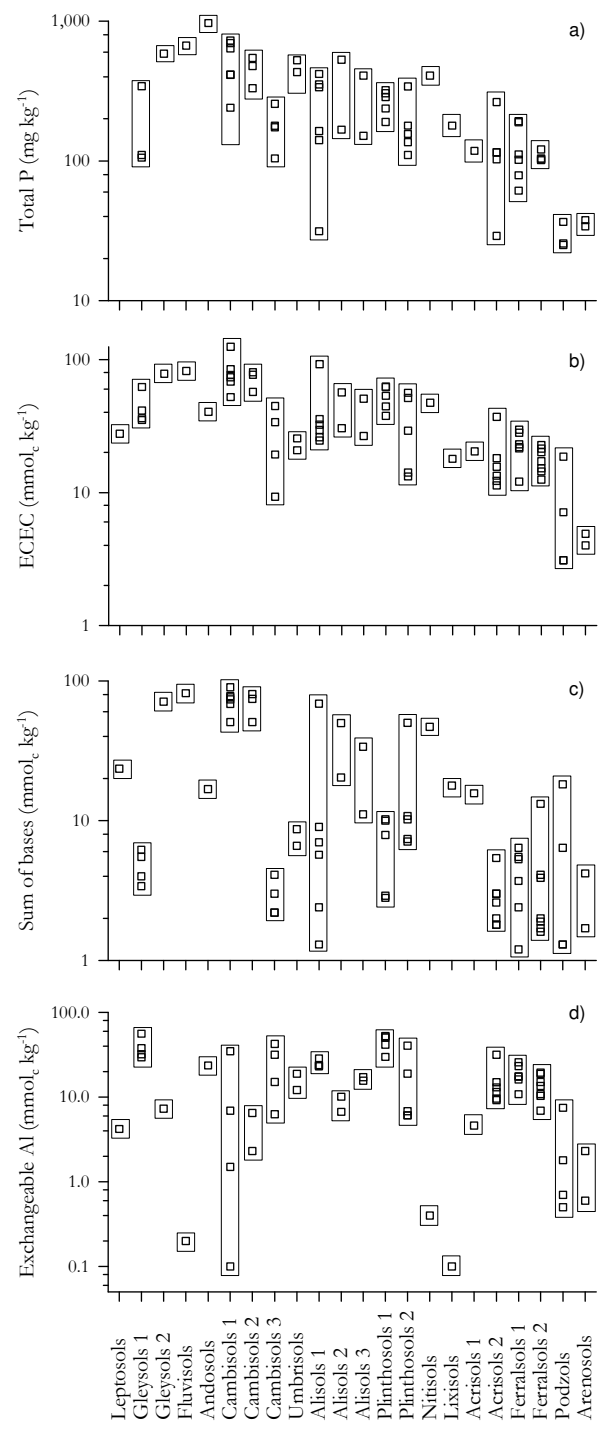

Reference Soil Group

Fig. 3. (a) and (b): Ranges of total phosphorus (top) and effective cation exchange capacity ( $I_{\mathrm{E}}$ below) across the soil age gradient. (c) and (d): Ranges of sum of bases $\sum_{\mathrm{B}}$ (top) and exchange aluminium $[\mathrm{Al}]_{\mathrm{E}}$ (below) across the soil age gradient.

$\Sigma_{\mathrm{B}}$ and $[\mathrm{Al}]_{\mathrm{E}}$ showing the highest degree of variations within some soil types (Fig. 3c and d, respectively). Some differences appear for $[\mathrm{Al}]_{\mathrm{E}}$ with values peaking and being equally high across Plinthosols, Alisols and for most Gleysols and Cambisols close to the Andes.

\subsection{Chemical and physical properties of Amazonian soils}

\subsubsection{Cations and soil reaction}

Figure 4 shows exchangeable cation levels for each site in this study, ordered by $\mathrm{Ca}$ concentration. Considerable variation is evident, with $\Sigma_{\mathrm{B}}$ being extremely low (less than $5 \mathrm{mmol}_{\mathrm{c}} \mathrm{kg}^{-1}$ ) for at least one third of the sites under study. For another third of the sites, slightly more favourable base cations level occur, sometimes coexisting with elevated $[\mathrm{Al}]_{\mathrm{E}}$. For the remaining sites, Ca was the dominant cation in the soil. However, for the great majority of sites in this study $[\mathrm{Al}]_{\mathrm{E}}$ accounts for the largest fraction of $I_{\mathrm{E}}$.

The distribution of exchangeable base cations and $\mathrm{Al}$ across the Basin was associated with a wide range of variation in soil pH, ranging from 3.7 to 6.2 (Fig. $5 \mathrm{a}$ and b, respectively). The highest $\mathrm{pH}$ values $(>5.5)$ occur in young - intermediate age base rich soils (Cambisols and Nitisols) which are also very low in $[\mathrm{Al}]_{\mathrm{E}}$. The $\mathrm{pH}$ of all other soils appears to be strongly governed by $[\mathrm{Al}]_{\mathrm{E}}$, with $\mathrm{pH}$ decreasing asymptotically as $[\mathrm{Al}]_{\mathrm{E}}$ increases. The highest $[\mathrm{Al}]_{\mathrm{E}}$ were found on young to intermediate age soils such as Gleysols, Cambisols and Plinthosols, but the lowest $\mathrm{pH}$ values were found on Acrisols and Ferralsols with $[\mathrm{Al}]_{\mathrm{E}}$ about half those found in such younger soils.

Although $[\mathrm{Al}]_{\mathrm{E}}$ dominates the exchange complex for many of the study sites (Fig. 4) of note are some sites where [Al] $\mathrm{E}$ occurs in unusually high concentrations, sometimes reaching values as high as $80 \mathrm{mmol}_{\mathrm{c}} \mathrm{kg}^{-1}$, this in some cases increasing with depth (see $[\mathrm{Al}]_{\mathrm{E}}$ profiles in Figs. 7a, 8, 10 and $16 \mathrm{~b}$ in Quesada et al. (2009a). This occurrence is exclusively associated to young and intermediate age soils such as Gleysols, Cambisols, Alisols and Plinthosols (Fig. 5b).

\subsubsection{Phosphorus}

Figure 6 shows the distribution of the different $\mathrm{P}$ fractions which varied widely. About two thirds of the sites had less than $100 \mathrm{mg} \mathrm{kg}^{-1}$ of $\mathrm{P}$ in the total extractable fraction and about one third had $\mathrm{P}_{\mathrm{TE}}$ less than $50 \mathrm{mg} \mathrm{kg}^{-1}$. Nevertheless, for some sites much higher $\mathrm{P}$ pools were observed, often 5 to 10 times higher than the lowest $\mathrm{P}$ sites and also having higher proportions of the more labile forms of $\mathrm{P}\left(\mathrm{NaHCO}_{3}\right.$ and resin fractions). Calcium bound $\mathrm{P}(\mathrm{HCl}$ fraction) was seldom found and when present was only a minor fraction. A comparison between P and cations levels (Figs. 6 and 4) shows that high levels of $\mathrm{P}$ are not necessarily accompanied by high base cations concentrations: There being sites with low $\Sigma_{\mathrm{B}}$ but high $\mathrm{P}_{\mathrm{TE}}$ levels (numbers 1 to 5 in both figures). Such sites also have high $[\mathrm{Al}]_{\mathrm{E}}$ which may be an indication of active mineral weathering (Quesada et al., 2009a).

Phosphorus distribution in each fraction and average content in each fraction is given per RSG in Fig. 7 with Table 4 showing the range of variation, the median and the average for $\mathrm{P}_{\mathrm{T}}$ and $\mathrm{P}_{\mathrm{TE}}$ for each Reference Soil Group as well as for lower classification levels. Arenosols and Podzols have the lowest $\mathrm{P}_{\mathrm{T}}$ with most of it found in bio-available forms and with little residual P. Ferralsols and Acrisols have higher P pools than do Podzols and Arenosols but with a high proportion of their $\mathrm{P}$ in unavailable, residual forms (0.53-0.67), and most of their bio-available $\mathrm{P}$ found in the inorganic $\mathrm{NaOH}$ 


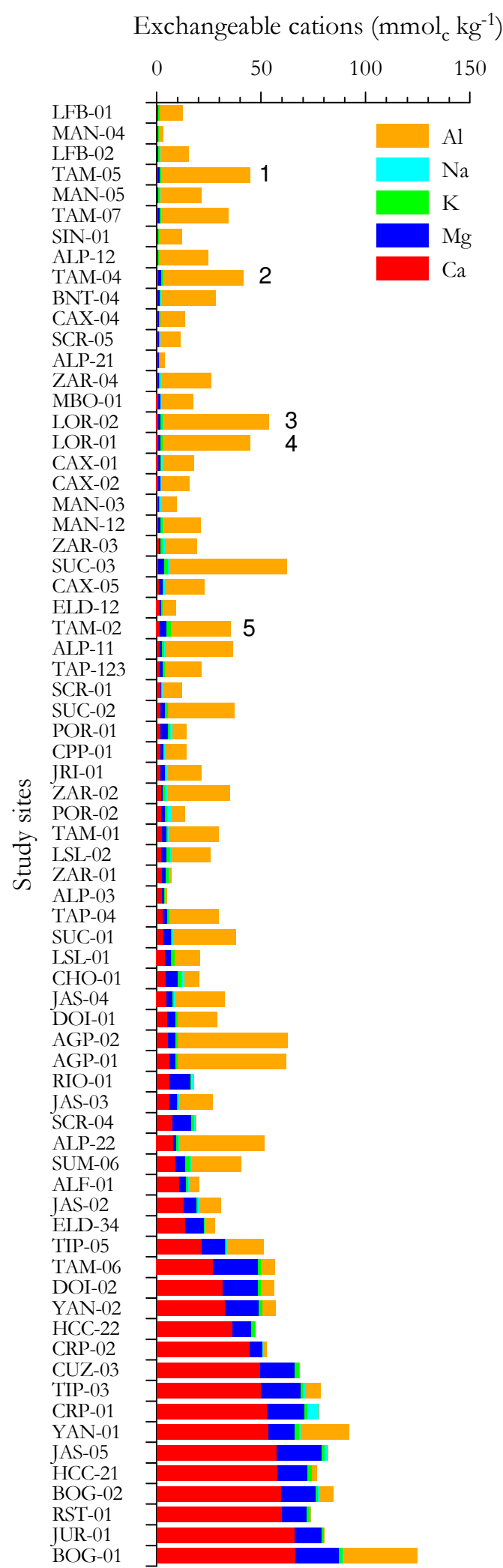

Fig. 4. Exchangeable cations concentrations for each study site, ordered by Ca concentration. See text for numbers.
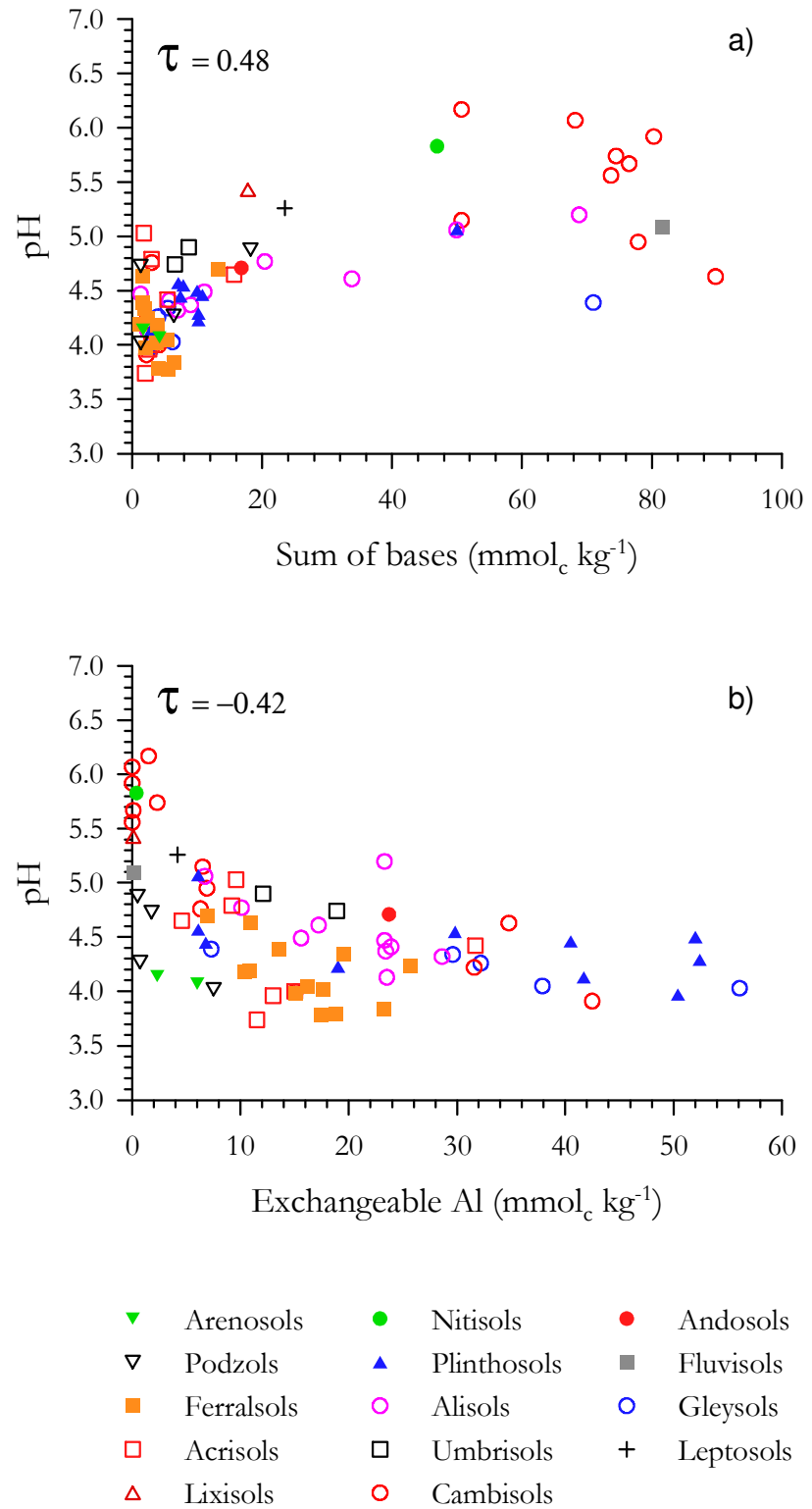

Fig. 5. (a) and (b): Relationship between soil pH and sum of bases (top) and exchangeable aluminium (below). Values of Kendall's $\tau$ rank correlation coefficient are also shown for which values $>0.19$ can be taken as significant at $\mathrm{P}=0.05$.

fraction as well as in organic forms. Average contents among lower classification Ferralsols and Acrisols were very similar but the proportion in each fraction varied slightly. Geric Ferralsols (Ferralsols 1 ) had about 0.14 more $\mathrm{P}$ in the residual pool than did Geric Acric Ferralsols (Ferralsols 2), with the latter having a larger $\mathrm{NaOH}$ organic pool. Differences existed between Lixisols, Acrisols and Ferralsols, but there was little difference in average bio-available pools among the three groups, with most of the difference (if not all) being associated with residual P. The Lixisol had the highest 


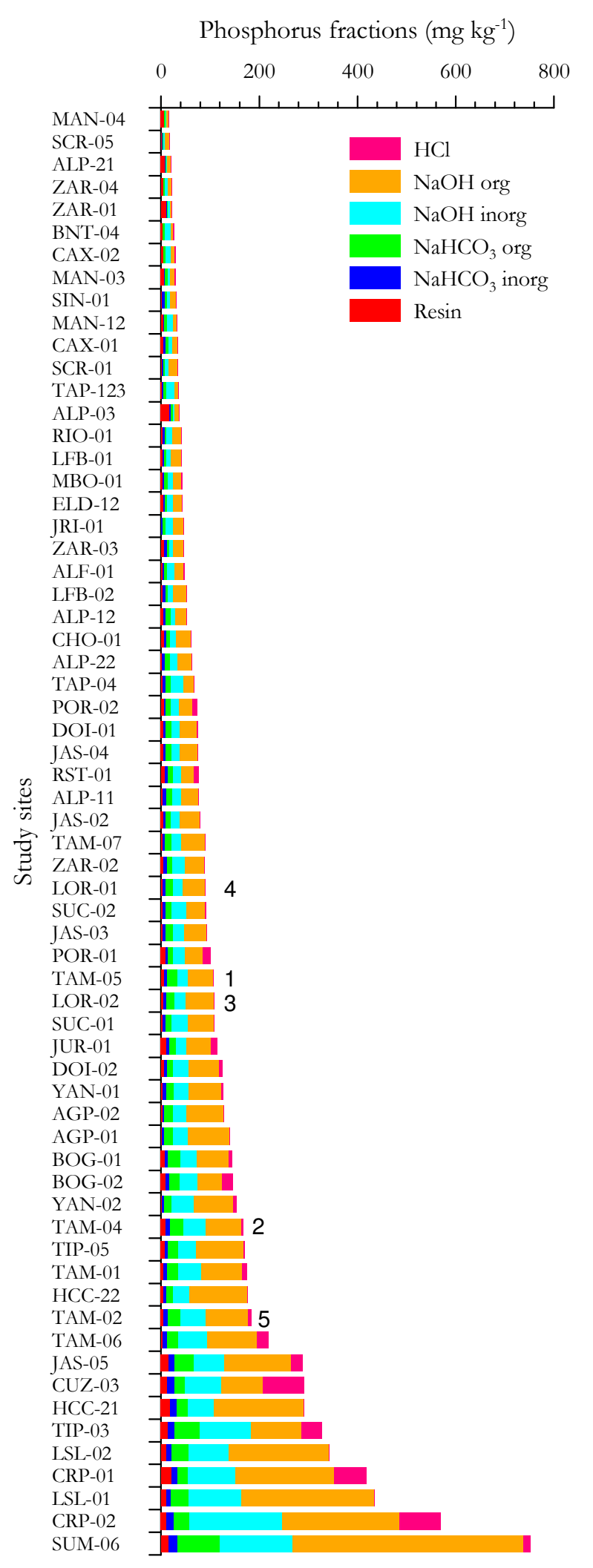

Fig. 6. Phosphorus concentrations per extractable fraction for each study site. Residual phosphorus was not included.
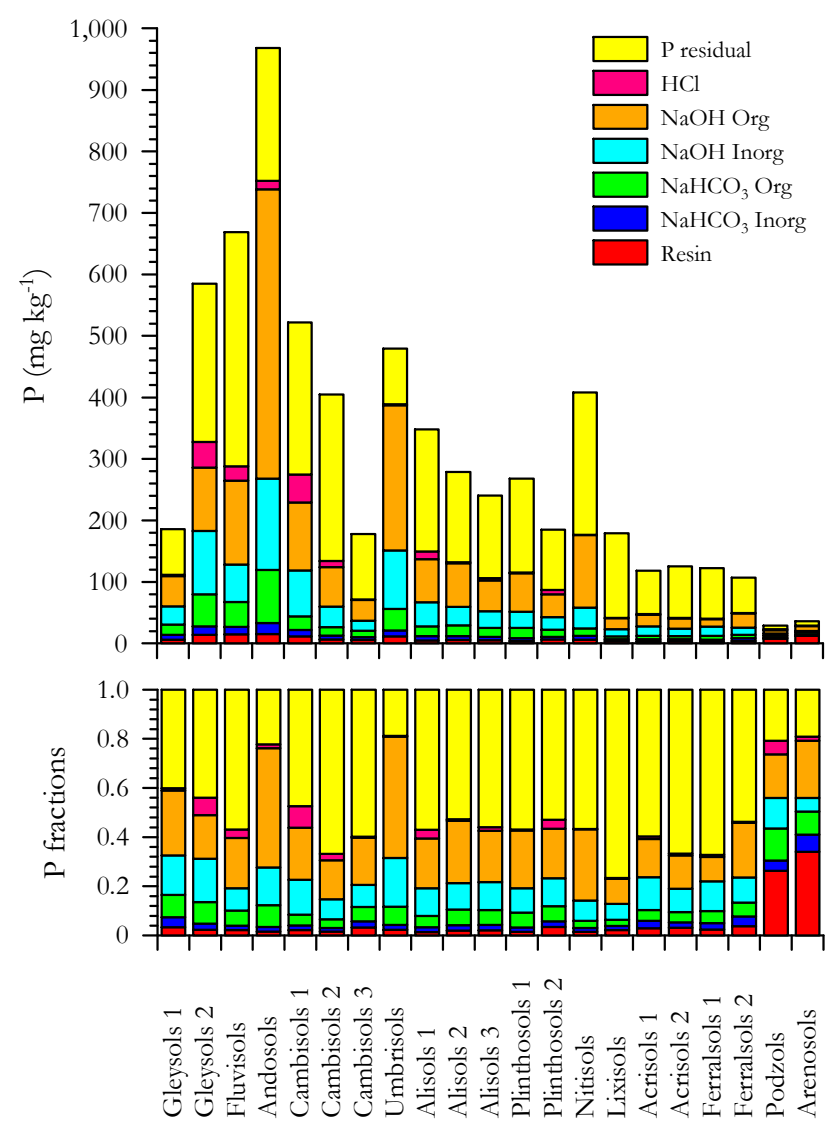

Fig. 7. Average phosphorus concentration in each fraction (top) and as fraction of total P (below) for each RSG and lower classification levels.

residual fraction observed in all soils $(>0.76)$. Nitisols had a much larger $\mathrm{P}$ pool, about two or three times higher than those of average Ferralsols/Acrisols, for which residual $\mathrm{P}$ accounted for more than 0.50 . From the bio-available fractions, $\mathrm{NaOH}$ extractable $\mathrm{P}$ was the dominant pool, especially the organic fraction. Phosphorus pools in the intermediate age Plinthosols and Alisols had similar P distribution among fractions but average amounts were slightly higher in Alisols.

The $\mathrm{HCl}$ pool was only of a minor importance in the younger soil groups, only occurring in trace amounts for the older soils. A gradient in P pools appears within the Alisols with decreasing pools from Alisols 1 to 3 and between Plinthosols 1 and 2. Umbrisols had P pools well above their precedent groups, also having the smallest proportion of residual $\mathrm{P}$. The $\mathrm{NaOH}$ organic was the largest pool, as would be expected for these organic matter rich soils. Cambisols showed the largest within RSG variation, with total extractable pools ranging from 77 to $570 \mathrm{mg} \mathrm{kg}^{-1}$ (Table 4) and with $\mathrm{P}_{\mathrm{T}}$ ranging from 104 to $727 \mathrm{mg} \mathrm{kg}^{-1}$. Average pools decreased following the sequence Orthoeutric $>$ Hyperdystric $>$ Hyperdystric Alumic (Cambisols 1 to 3 ) whilst residual 
Table 4. Average values, median and range of variation, of total extractable $\mathrm{P}$ and $\mathrm{P}$ total for each Reference Soil Group and lower classification levels.

\begin{tabular}{|c|c|c|c|c|c|c|c|c|}
\hline RSG & Average & Median & Max & Min & Average & Median & Max & Min \\
\hline & & $\mathrm{P}_{\text {TOTAL }}$ & & & & $\mathrm{P}_{\mathrm{TE}}$ & & \\
\hline Gleysols 1 & 185.9 & 110.3 & 342.2 & 105.4 & 111.5 & 90.2 & 167.1 & 77.2 \\
\hline Gleysols 2 & 584.8 & & & & 327.3 & & & \\
\hline Fluvisols & 668.5 & & & & 288.0 & & & \\
\hline Andosols & 968.2 & & & & 752.1 & & & \\
\hline Cambisols 1 & 522.1 & 527.4 & 727.0 & 240.2 & 274.3 & 101.2 & 569.7 & 77.0 \\
\hline Cambisols 2 & 451.3 & 477.3 & 544.6 & 331.9 & 186.6 & 153.8 & 291.9 & 114.2 \\
\hline Cambisols 3 & 178.1 & 175.9 & 256.3 & 104.1 & 71.5 & 67.7 & 107.0 & 43.9 \\
\hline Umbrisols & 479.3 & & 525.4 & 433.1 & 388.8 & & 434.7 & 342.8 \\
\hline Alisols 1 & 240.7 & 250.3 & 418.5 & 31.4 & 106.0 & 101.2 & 184.5 & 22.0 \\
\hline Alisols 2 & 348.0 & & 528.8 & 167.3 & 149.4 & & 219.0 & 79.8 \\
\hline Alisols 3 & 279.0 & & 407.1 & 150.9 & 132.0 & & 170.7 & 93.2 \\
\hline Plinthosols 1 & 267.9 & 286.7 & 319.9 & 190.4 & 115.3 & 109.3 & 140.5 & 90.8 \\
\hline Plinthosols 2 & 184.6 & 155.8 & 341.7 & 110.2 & 86.9 & 75.2 & 124.0 & 62.6 \\
\hline Nitisols & 407.8 & & & & 176.6 & & & \\
\hline Lixisols & 179.0 & & & & 41.8 & & & \\
\hline Acrisols 1 & 118.1 & & & & 47.6 & & & \\
\hline Acrisols 2 & 125.2 & 115.0 & 263.9 & 29.1 & 41.6 & 34.3 & 91.2 & 18.4 \\
\hline Ferralsols 1 & 122.5 & 106.6 & 192.3 & 61.3 & 40.1 & 34.5 & 67.7 & 26.8 \\
\hline Ferralsols 2 & 107.2 & 103.3 & 120.7 & 101.4 & 49.5 & 47.5 & 61.1 & 41.8 \\
\hline Arenosols & 35.8 & & 37.6 & 34.0 & 29.0 & & 37.2 & 20.8 \\
\hline Podzols & 29.1 & 25.7 & 36.5 & 25.0 & 23.0 & 22.6 & 29.5 & 16.9 \\
\hline
\end{tabular}

pools increased slightly in the same order. Cambisols had the highest $\mathrm{HCl}$ fraction of all studied soils, with this fraction also decreasing markedly from Cambisols 1 to 3 . The one Andosol studied had the highest $\mathrm{P}$ pools, with the $\mathrm{NaOH}$ organic fraction being extremely high. As well as having the largest pools, the residual fraction was among the smallest found. It also had an appreciable $\mathrm{HCl}$ fraction (Ca-P).

From Fig. 3a it can also be seen that $\mathrm{P}$ pools for the youngest soils were consistently lower than in the intermediate age ones, but still many times higher than for the most well weathered soils. This suggests a general pattern with $\mathrm{P}$ pools increasing from the youngest to the youngintermediate age soils and then declining gradually towards the most weathered ones. Within the Gleysols, average $\mathrm{P}$ content increased in the sequence Hyperdystric Alumic < Orthoeutric (Gleysols 1 and 2), as did the $\mathrm{HCl}$ fraction. Despite having a smaller $\mathrm{P}_{\mathrm{T}}$, Gleysols 1 had a lower fraction of residual $\mathrm{P}$ than in the more fertile Gleysols 2, while the Fluvisols had an even higher average $P$ content but with a much higher residual proportion than both Gleysols 1 and 2.

In terms of general trends across soil types, it is clear that $\mathrm{P}_{\mathrm{T}}$ varies considerably across the age gradient (Fig. 3a). Residual $\mathrm{P}$ is highest in the Lixisols, Acrisols and Ferralsols and lower in young - intermediate soil orders such as Umbrisols, Andisols and many Cambisols and Gleysols. The residual fraction was very low in the sand rich Arenosols and Podzols but one should bear in mind that the soil properties governing the residual pools in sand rich soils must differ from all other soils in this study. All other soil orders had residual $\mathrm{P}$ varying between $0.40-0.50$ of the $\mathrm{P}_{\mathrm{T}}$. The readily available fractions (resin plus inorganic and organic bicarbonate) represent approximately the same fraction in all soil types with the exception of the sand rich soils which had totally different $\mathrm{P}$ distributions. For most soils in this study, the $\mathrm{Na}$ hydroxide fraction (organic and inorganic) accounted for most of the labile P present.

Figure 8 shows the relationship between $\mathrm{P}_{\mathrm{T}}$ and the chemically based weathering index, $\Sigma_{\mathrm{RB}}$. This shows that $\mathrm{P}_{\mathrm{T}}$ varies only slightly with increasing $\Sigma_{\mathrm{RB}}$ until a "break point" concentration is reached. Beyond this $\Sigma_{\mathrm{RB}}$ concentration of ca. $80 \mathrm{mmol}_{\mathrm{c}} \mathrm{kg}^{-1}, \mathrm{P}_{\mathrm{T}}$ then increases exponentially as $\Sigma_{\mathrm{RB}}$ increases. Distinctive soil groups occur along the relationship; soils with advanced weathering stage predominate in the first part, with the weathering gradient of Arenosols $>$ Podzols $>$ Ferralsols $>$ Acrisols $>$ Lixisols only being associated with slight increments in $\mathrm{P}_{\mathrm{T}}$. Nevertheless, Arenosols and Podzols can be seen to occupy the endpoint of the weathering spectrum with the lowest $\mathrm{P}_{\mathrm{T}}$ and $\Sigma_{\mathrm{RB}}$. Where young and intermediate aged soils predominate, variations in weathering degree and higher $\Sigma_{\mathrm{RB}}$ are associated with large increments in $\mathrm{P}_{\mathrm{T}}$.

The proportion of the $\mathrm{P}_{\mathrm{T}}$ that is assumed to be labile $\left(\mathrm{P}_{\mathrm{TE}}\right)$ varied among and within soil groups (Fig. 9a). For the Arenosols, between 0.6 to 1.0 of the $\mathrm{P}_{\mathrm{T}}$ pool was found 


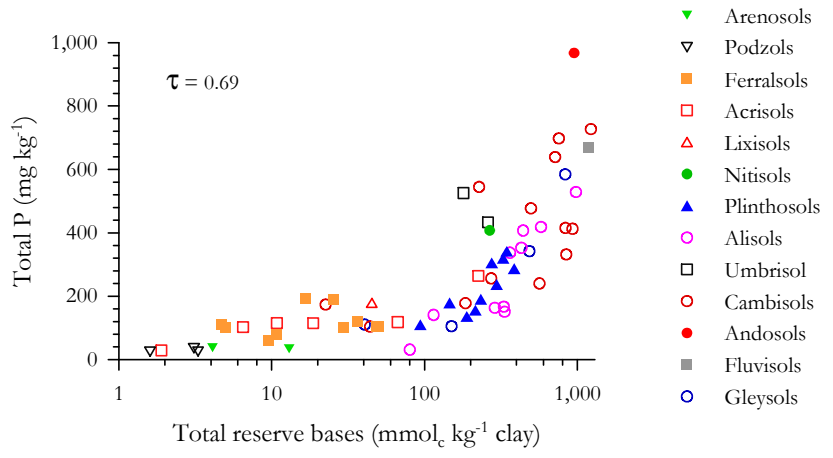

Fig. 8. Relationship between total phosphorus concentration and the chemical weathering index Total Reserve Bases $\left(\sum_{\mathrm{RB}}\right)$. Note that only $\mathrm{X}$-axis is in logarithmic scale. Values of Kendall's $\tau$ rank correlation coefficient are also shown.

as $\mathrm{P}_{\mathrm{TE}}$ whilst for Podzols it varied between 0.7 and 0.9. Amongst the non-sandy soils, Umbrisols and Andosols had the highest proportion $\left(\mathrm{P}_{\mathrm{TE}} \sim 0.8 \mathrm{P}_{\mathrm{T}}\right)$ with similar results occurring for some soils of the Gleysols and Cambisols group. On the other hand, Ferralsols had a much lower proportion with $\mathrm{P}_{\mathrm{TE}}$ varying from only 0.25 to a maximum of 0.5 of the $\mathrm{P}_{\mathrm{T}}$. Acrisols and Lixisols showed a similar pattern to those of Ferralsols, with $\mathrm{P}_{\mathrm{T}}$ for Acrisols varying from about 0.25 to 0.6 and only being 0.25 for the solitary Lixisol. For most of the other soils, $\mathrm{P}_{\mathrm{TE}}$ varied between 0.35 and 0.5 of $\mathrm{P}_{\mathrm{T}}$.

The fraction of $\mathrm{P}_{\mathrm{TE}}$ made up by organic $\mathrm{P}\left(\mathrm{P}_{\mathrm{ORG}}\right)$ is shown in Fig. 9b. Arenosols had their organic fraction varying between 0.35 and 0.45 of $\mathrm{P}_{\mathrm{TE}}$ while for podzols it varied between 0.25 and 0.5 . For Ferralsols, the same ratio varied from about 0.30 to 0.65 and these three highly weathered soil groups had similar distribution with the lowest organic proportions overall.

Acrisol $\mathrm{P}_{\mathrm{ORG}} / \mathrm{P}_{\mathrm{TE}}$ ranged between 0.4 and 0.6 ; the Lixisol had 0.5 whilst for the Alisols this ratio varied between 0.55 and 0.7. Plinthosols varied from 0.5 to 0.75 with Umbrisols, Nitisols and Andosols having an organic fraction constituting about $0.8 \mathrm{P}_{\mathrm{TE}}$. Cambisols were again variable, $\mathrm{P}_{\mathrm{ORG}} / \mathrm{P}_{\mathrm{TE}}$ ranging from 0.4 to 0.7 with the Fluvisols having a ratio of about 0.6 and Gleysols ranging from 0.5 to 0.65 . In general the fraction $\mathrm{P}_{\mathrm{TE}}$ present in the organic form tended to decrease with weathering and pedogenic evolution.

\subsubsection{Soil carbon and nitrogen}

Similar to the other soil properties described above, $0-0.3 \mathrm{~m}$ carbon, $[\mathrm{C}]$, and nitrogen, $[\mathrm{N}]$, varied systematically across the age gradient with two distinct patterns distinguishable (Fig. 10). Carbon has high values for the youngest soils (from Leptosols to Umbrisols), but then shows a gradual decrease from Alisols to Plinthosols and, after a peak for the Nitisols, continues to decline until the Acrisols (Fig. 10a). A contrasting pattern appears in the most weathered sequence
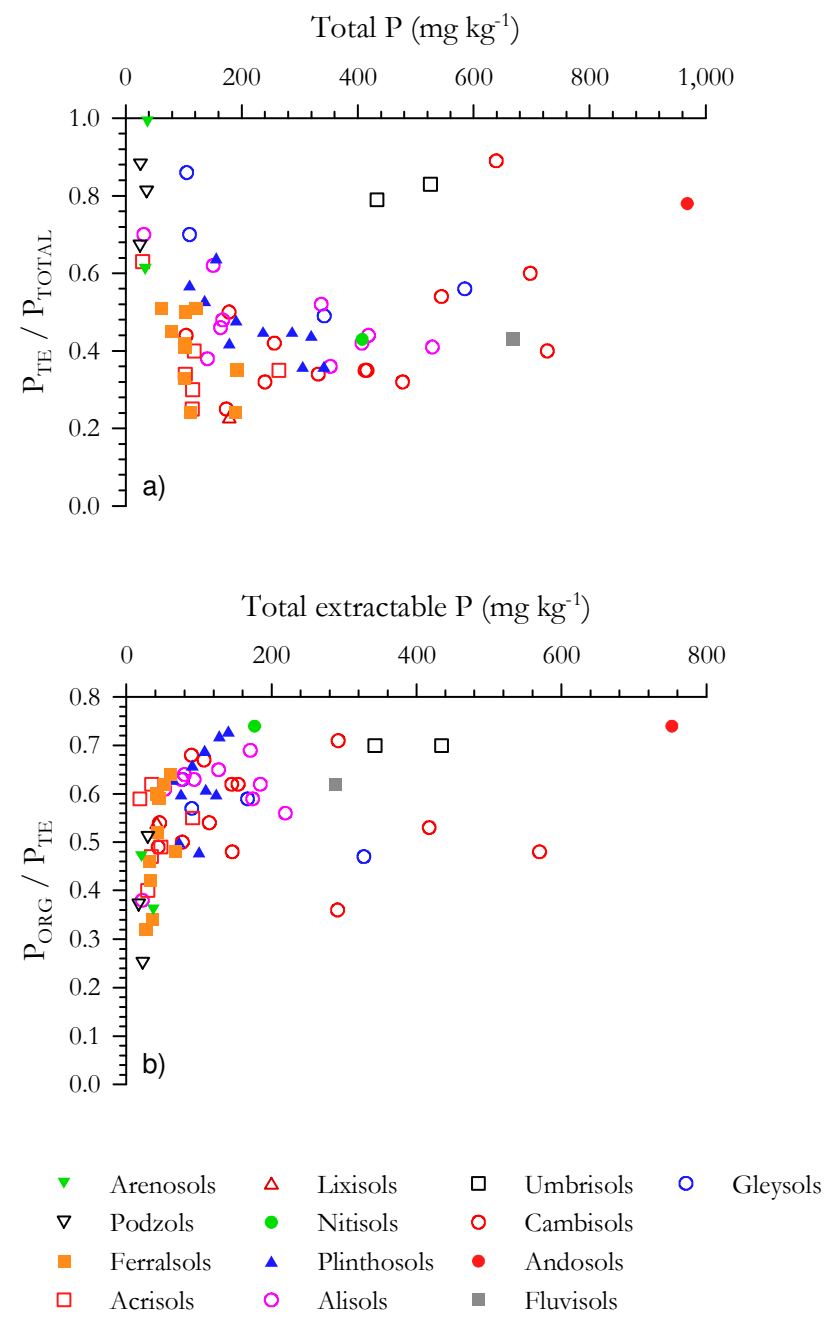

Fig. 9. (a) and (b): Variations in the proportion of total phosphorus pool which is assumed to be labile (total - residual, top chart), and the fraction of such labile pool which is formed by organic phosphorus (below).

Acrisols - Ferralsols - Podzols where [C] gradually increases with soil pedogenic development, but again declining in the Arenosols. The distribution of soil nitrogen mirrors that of $[\mathrm{C}]$ but with $[\mathrm{N}]$ showing a slightly steeper decline across the age gradient, in particular between Cambisols and Acrisols (Fig. 10b). Also, despite [N] showing a similar sequence of peaks in the Acrisols - Ferralsols Podzols as for carbon, $[\mathrm{N}]$ were relatively low when considering the amount of carbon in these soils. As a consequence, the carbon to nitrogen ratio (C:N ratio; Fig. 10c) also varied across the age gradient. Most of the young and intermediate soils had a ratio of around 10 , with appreciably higher values in the older soils such as Acrisols, Ferralsols and Podzols.

In Fig. 11 soil $\delta^{15} \mathrm{~N}$ is plotted as a function of $\mathrm{P}_{\mathrm{TE}}$. Noting that the degree of enrichment of soil $\delta^{15} \mathrm{~N}$ can be taken as a rough measure of the degree of openness of the nitrogen 

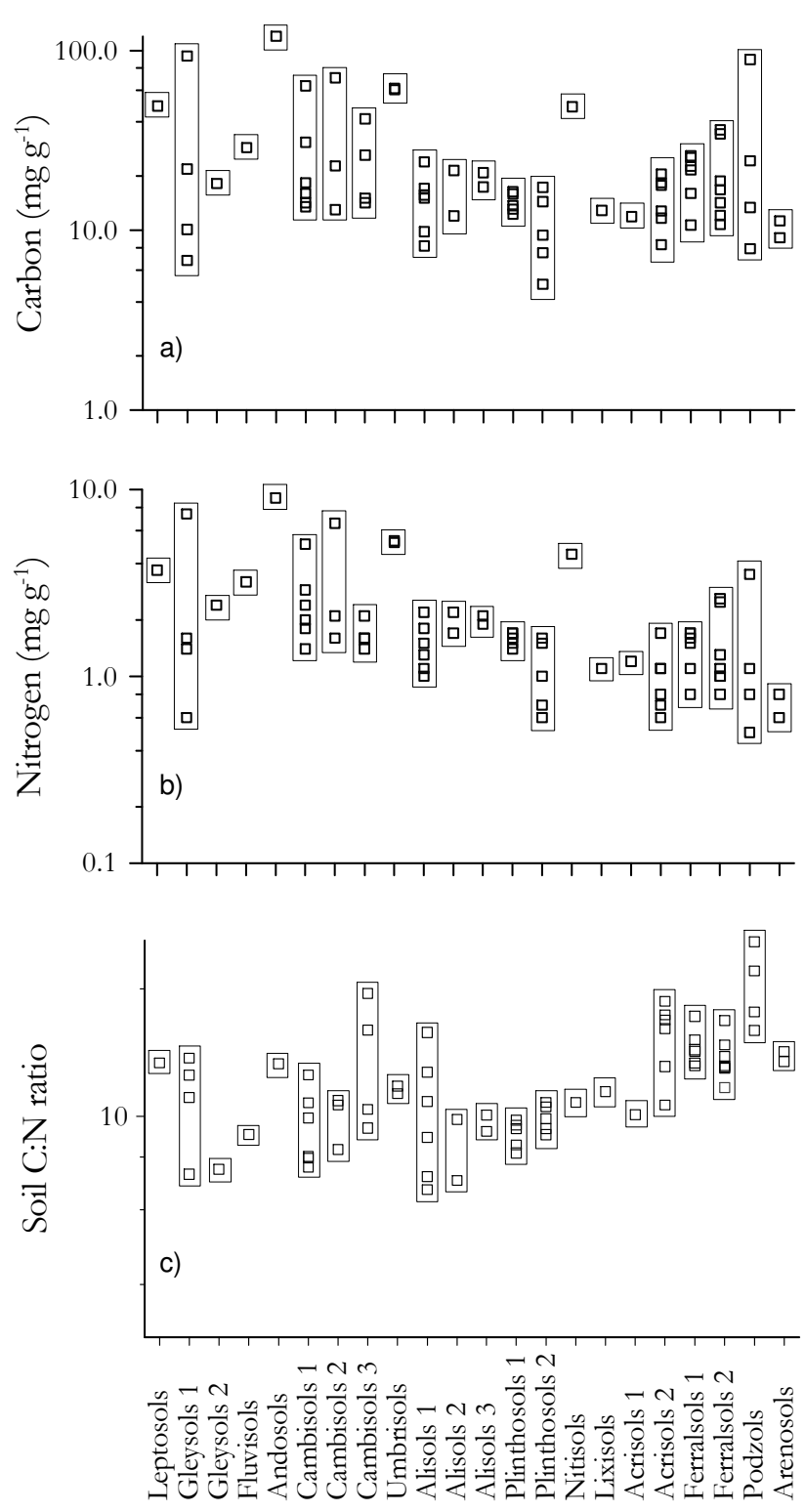

Reference soil Group

Fig. 10. Variations in soil carbon (top), nitrogen (mid) and C:N ratio (below) across the soil age gradient.

cycle (Högberg, 1997; Martinelli et al., 1999) this suggests systematic variations in the openness of the nitrogen cycle in association with changes in P availability. From the viewpoint of declining soil phosphorus status during pedogenesis (i.e. moving from right to left) it can be seen that a gradual enrichment of soil $\delta^{15} \mathrm{~N}$ first occurs as $\mathrm{P}_{\mathrm{TE}}$ declines, this being more or less uniform across all soil types, until a critical point is reached at $\mathrm{P}_{\mathrm{TE}} \sim 30 \mathrm{mg} \mathrm{kg}^{-1}$. Below this "threshold" a precipitous decline in $\delta^{15} \mathrm{~N}$ occurs. Arenosols and Podzols predominate in this side of the curve but it is emphasised that

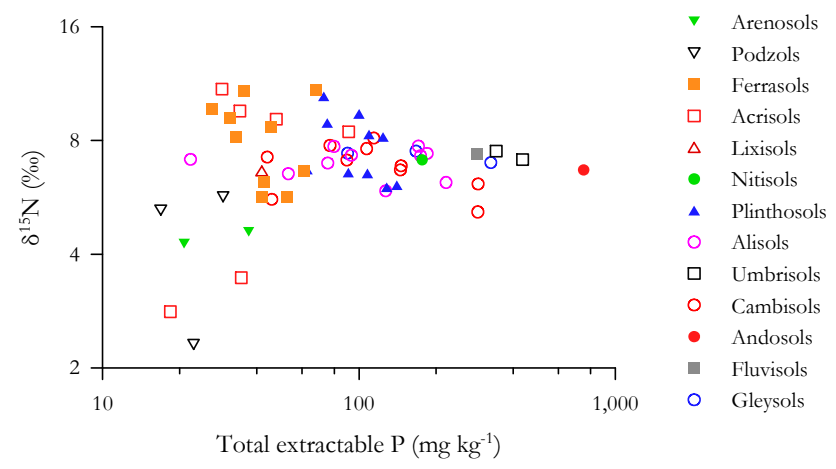

Fig. 11. Relationship between soil $\delta^{15} \mathrm{~N}$ and the total extractable $\mathrm{P}$ pool.

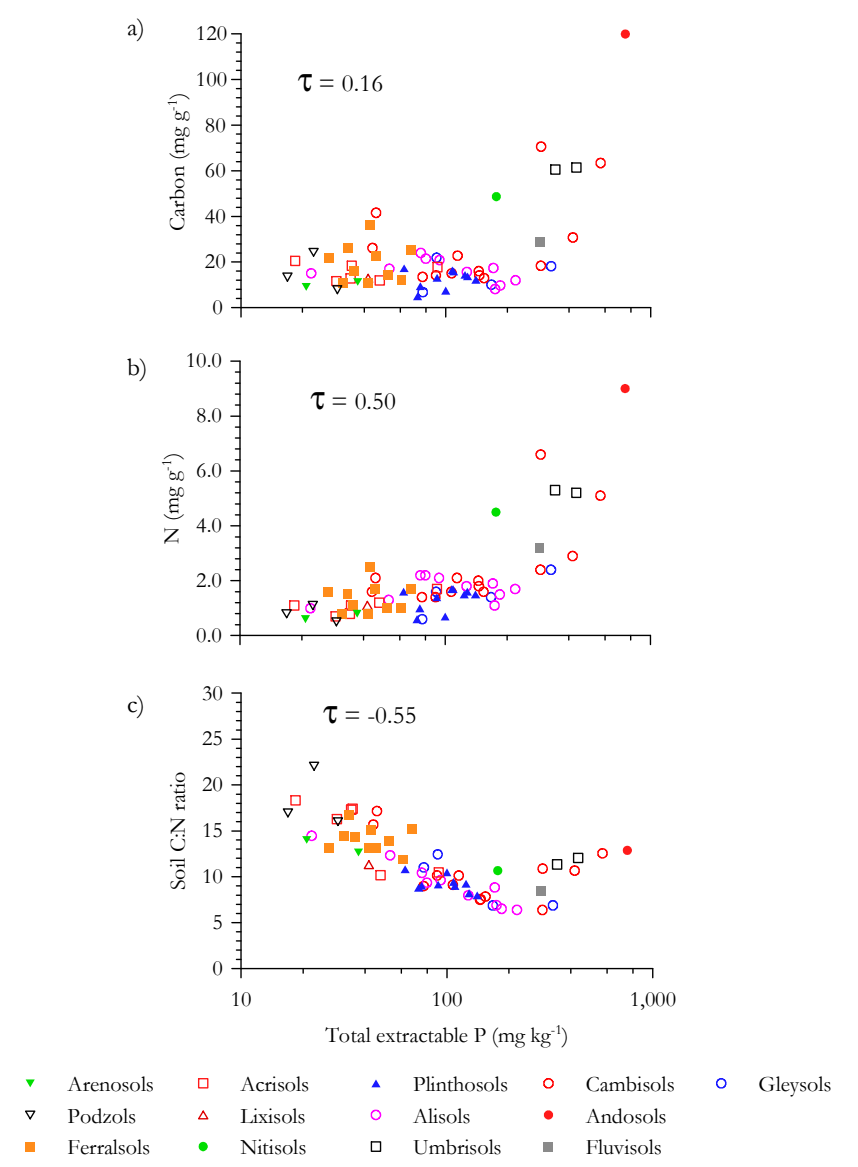

Fig. 12. Influence of soil phosphorus over concentrations of carbon (a), nitrogen (b) and C:N ratio (c). Values of Kendall's $\tau$ rank correlation coefficient are also shown.

soils of low P status from other groups such as Acrisols and Alisols are also present in this dramatically different phase of the $\delta^{15} \mathrm{~N}$ versus $\mathrm{P}_{\mathrm{TE}}$ relationship.

In addition to the observed relationship between $\mathrm{P}_{\mathrm{TE}}$ and $\delta^{15} \mathrm{~N}$, differences in soil $\mathrm{P}$ status also showed strong 
relationships with the soil carbon and nitrogen pools (Fig. 12). Although $\mathrm{P}_{\mathrm{TE}}$ did not show any relationship with [C] below $\mathrm{P}_{\mathrm{TE}} \sim 200 \mathrm{mg} \mathrm{kg}^{-1}$, above that $[\mathrm{C}]$ increased linearly with increments in $\mathrm{P}_{\mathrm{TE}}$ (Fig. 12a). Nitrogen showed a similar response but, different to carbon, $[\mathrm{N}]$ also showed a linear threefold increment with $\mathrm{P}$ supply below the $200 \mathrm{mg} \mathrm{kg}^{-1}$ (Fig. 12b). As a result, soil C:N was strongly related to $\mathrm{P}_{\mathrm{TE}}$ (Fig. 12c), declining strongly as $\mathrm{P}$ increases, but also with the soils with the highest $\mathrm{P}_{\mathrm{TE}}$ deviating somewhat from that relationship.

\subsubsection{Physical properties}

Figure 13 shows observed scores for soil physical properties, plotted against a pedogenetic gradient of increasing substrate age. Figure 13 shows physical constraints to be associated with soil type and pedogenic level, with the young and intermediate age soils generally showing high scores and with soils at advanced stages of weathering, especially Ferralsols, showing zero or very low scores. The lowest incidence of physical constraints thus occurs in the Ferralsols group where, from the thirteen samples studied, eleven did not have any physical impediment identified at all. Podzols and Arenosols were relatively variable, with any scores assigned usually associated with water saturation. Although two samples did not show any physical constraint, Acrisols generally had structure limitations associated with their clay accumulation zones. Soils with intermediate to advanced weathering such as Nitisols and Lixisols had relatively low $\Pi$ while soils at the lowest pedogenic levels such as those occurring between the Leptosols and Plinthosols groups had a large variation, but with a predominantly high occurrence of physical constraints. Conditions associated with these soil groups were shallow soil and rooting depth, steep topography, structural and drainage deficiencies: these all occurring to various degrees and in different combinations.

Considering that physical conditions are to some degree related to pedogenic level, one could anticipate that $\Pi$ must have some relationship with weathering intensity and, indeed $\Sigma_{\mathrm{RB}}$ increases asymptotically with $\Pi$, with the lowest values related to index scores between 0 and 2 (Fig. 14). Beyond the threshold $\Sigma_{\mathrm{RB}} \sim 80 \mathrm{mmol}_{\mathrm{c}} \mathrm{kg}^{-1}$ (see Fig. 8) almost all soils had high index scores. Figure 15 also shows this "trade off" between soil elemental concentrations and limiting physical properties, with increasing $\Pi$ correlated with increments in both $I_{\mathrm{E}}$ and $\mathrm{P}_{\mathrm{TE}}$ Thus favourable physical conditions generally only occur on older substrates of low fertility.

\subsubsection{Principal component analysis}

Figure 16 shows a principal component analysis for the soil properties analysed as part of this study, this representing a summary of the main relationships occurring. The first component explains 0.50 of the variation and reflects the importance of a continuum in the weathering stage of the

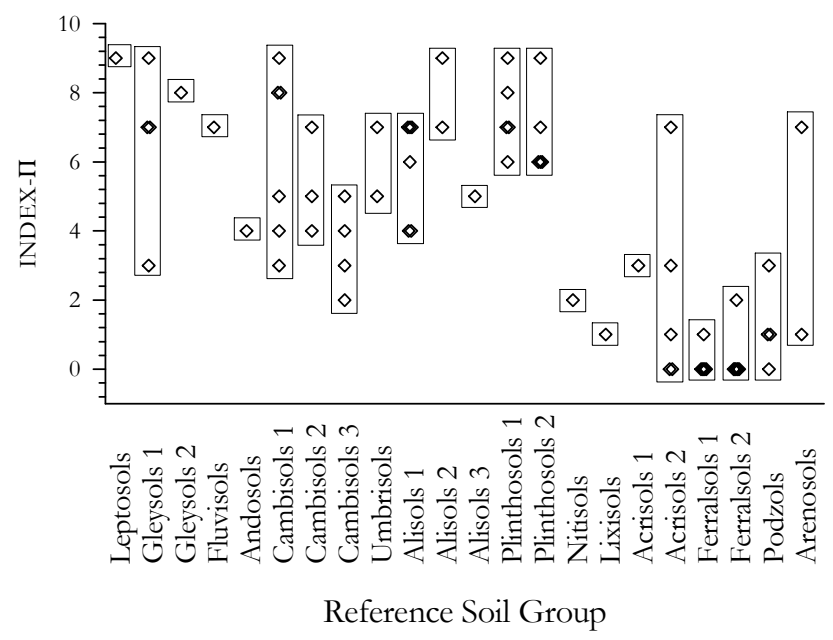

Fig. 13. Variation in the index of physical properties (П) along the soil age gradient. Bars represent the variability within soil groups, and thicker and darker marks reflect many data points sharing the same score.

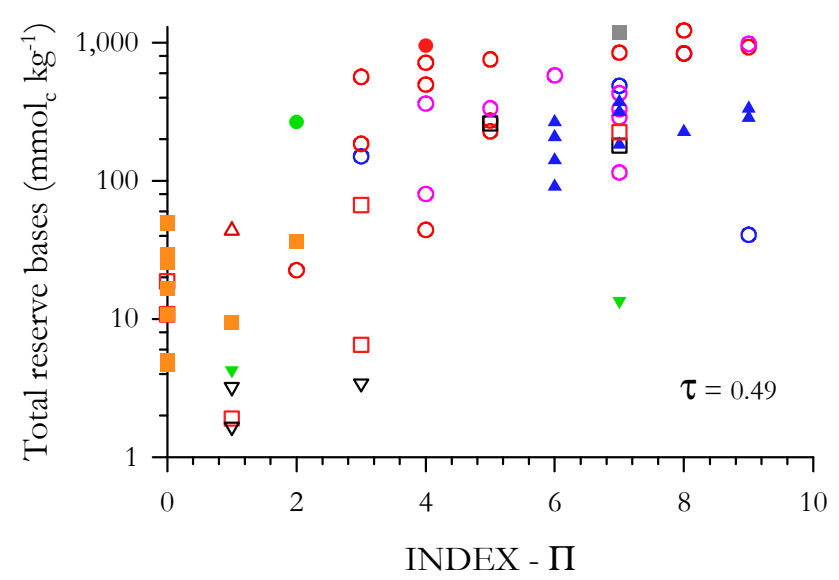

Fig. 14. Relationship between the index of physical properties (П) and the chemical weathering index Total Reserve Bases $\left(\sum_{\mathrm{RB}}\right)$. Note that only Y-axis is in logarithmic scale. Values of Kendall's $\tau$ rank correlation coefficient are also shown.

soil ( $\left.\Sigma_{\mathrm{RB}}: 0.356\right)$ being strongly related to soil phosphorus $\left(\mathrm{P}_{\mathrm{T}}: 0.369, \mathrm{P}_{\mathrm{TE}}: 0.354\right)$, bases availability $\left(\Sigma_{\mathrm{B}}: 0.323\right)$ and $I_{\mathrm{E}}(0.348)$. The second axis explained 0.17 of the variation and was dominated by $\mathrm{pH}(0.469),[\mathrm{Al}]_{\mathrm{E}}(0.446)$ and the clay $(0.415)$ and sand fractions (0.389). The third axis included $[\mathrm{C}](0.570),[\mathrm{N}](0.411)$, clay fraction $(0.355)$, $\Pi(0.353)$ and $\mathrm{C}: \mathrm{N}$ ratio $(0.342)$ and explained a further 0.14 of the variation. In total, these first three axes explained 0.82 of the total variation in the chemical and physical properties of Amazon forest soils. 


\section{Discussion}

\subsection{Distribution of soil types, soil fertility and physical properties across Amazonia}

The diversity of soil types (Fig. 1) and the large variation in soil fertility and physical properties observed (Fig. 2) originate from well-known geomorphologic variations (Irion, 1978) as well as ongoing transformations occurring during ecosystem development (Walker and Syers, 1976). The eastern and central areas of Amazonia, in particular those in the vicinity of the Amazon River (Fittkau, 1971), have soils mainly derived from rocks and reworked sediments from the middle Tertiary period with a high probability to belong to the end of Cretaceous. Thus such soils have experienced more or less continuous weathering for more than 20 million years (Irion, 1978). In addition to the lack of recent geological activity, the sediments deposited in that region normally would have had a very low nutrient content (Fittkau et al., 1975). Also, high topographic stability combined with continuous hot and wet weather has resulted in a deep weathering and leaching of parent material, eliminating bedrock as a source of nutrients for most of that region. Extending from the north and south borders of Amazonia lies the older crystalline Guyana and Brazilian shields, of Cretaceous age. Despite being very old surfaces, soils developed in the crystalline shields often had lower pedogenic development than soils found in the reworked sediments of central Amazonia. On the other hand, the western portion of Amazonia consists of much more recent pre-Andine sediments from the Cretaceous-Tertiary period, but uplifted in the Pliocene. This formation must have commenced between 1 and 2 million years ago. Recent floodplain soils from the Pleistocene and Late Holocene are also common in that region and they should not be much older than 5000 years. In addition, the western Amazonian areas have large areas where shallow soils on hill slopes dominate. Thus, a high contribution of weathering of parent material to fertility of overlying soils can be expected (Irion, 1978; Jordan and Herrera, 1981). Thus contrasting geology, geomorphology and age of parent material are reflected in soil nutrient contents and their distribution across Amazonia, as inferred by Fittkau (1971) from nutrient measurements in natural waters occurring in each region. He showed that soils occupying the western portion of Amazonia all had high nutrient concentrations. On the other hand, soils in the vicinity of the Amazon River (central-eastern portion of Amazonia) all had a very low amount of nutrients, with the soils occupying the crystalline shields having intermediate nutrient levels.

As is the case for fertility, soil physical properties are intrinsically related to geomorphology and soil age. Highly weathered soils commonly found in old weathering surfaces typically have depths of several metres above the parent material and usually have very good physical conditions (i.e. deep, well aggregated and well drained). This is a result
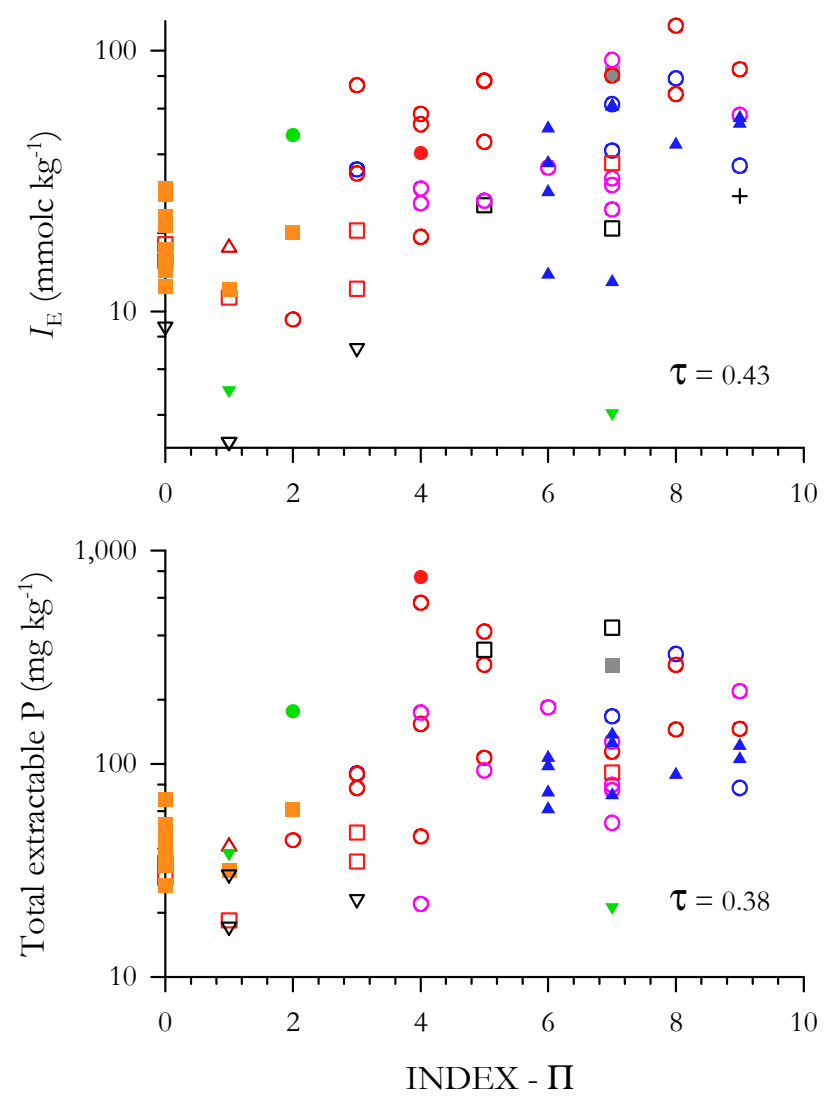

$\begin{array}{llllll}\nabla & \text { Arenosols } & \bullet & \text { Nitisols } & \bullet & \text { Andosols } \\ \nabla & \text { Podzols } & \Delta & \text { Plinthosols } & \square & \text { Fluvisols } \\ \square & \text { Ferralsols } & \circ & \text { Alisols } & \circ & \text { Gleysols } \\ \square & \text { Acrisols } & \square & \text { Umbrisols } & + & \text { Leptosols } \\ \Delta & \text { Lixisols } & \circ & \text { Cambisols } & & \end{array}$

Fig. 15. Trade off between soil element concentrations and limiting physical properties. Effective cation exchange capacity ( $I_{\mathrm{E}}$, top) and total extractable phosphorus (below) co-vary with soil physical limitations. Values of Kendall's $\tau$ rank correlation coefficient are also shown.

of millenniums of soil development (Sanchez, 1987). On the other hand, the younger but more fertile soils in Amazonia occur on more recent weathering surfaces and have their physical properties closely related to their lower pedogenic levels. This generally arises as a consequence of associations with dissected topography, bad drainage and/or deposition of sediments by flooding waters (Irion, 1978; Herrera et al., 1978).

Prior to this work, the only large scale study of Amazonian soils was the RADAM-BRASIL soil survey (RADAMBRASIL, 1978). Compare both studies is difficult given that both had different aims but perhaps the main advance of this study over the RADAM-BRASIL soil survey 


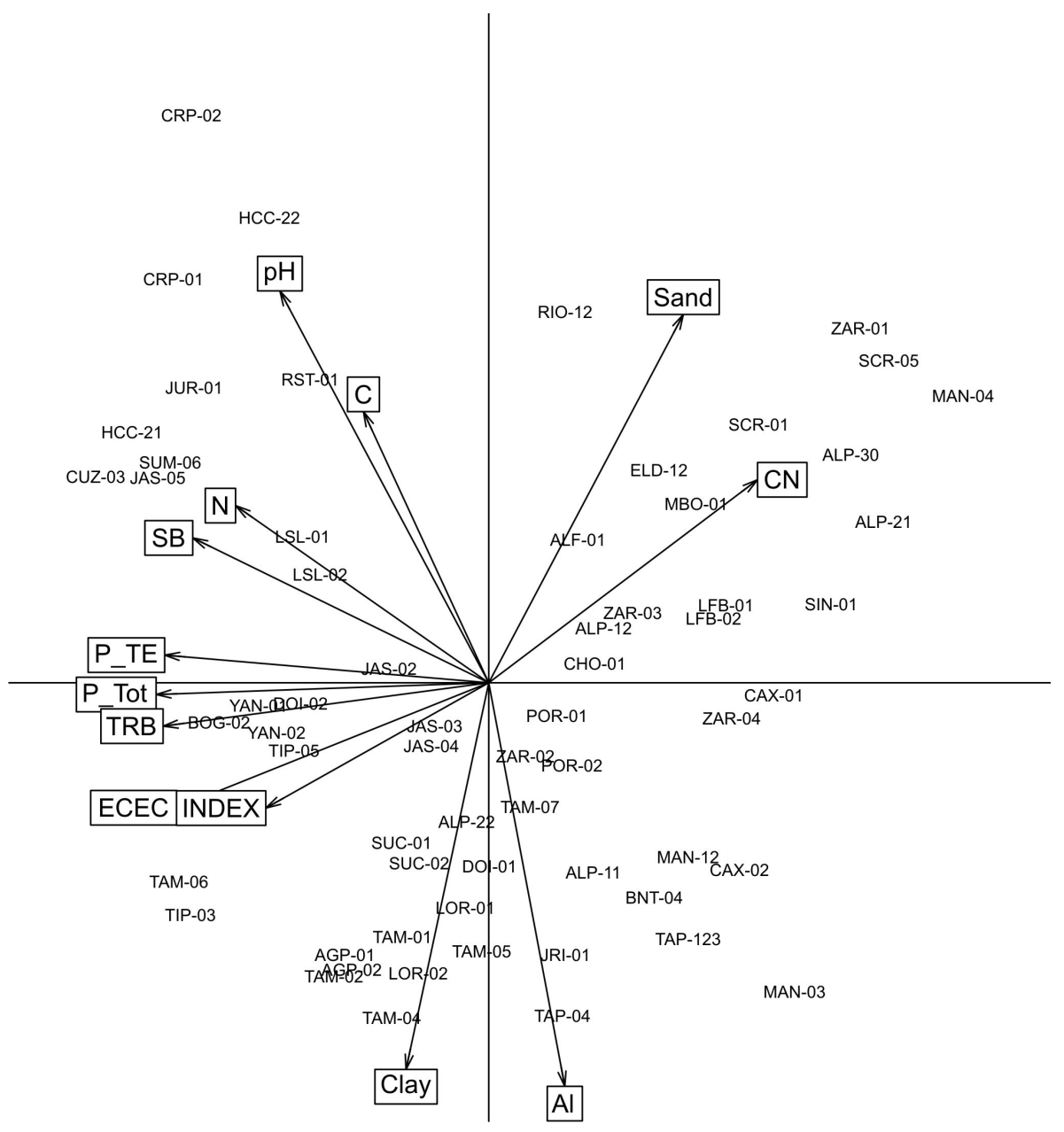

\begin{tabular}{|c|c|c|c|c|c|c|}
\hline & Axis 1 & Axis 2 & Axis 3 & Axis 1 & Axis 2 & Axis 3 \\
\hline & \multicolumn{3}{|c|}{ Eigenvectors } & \multicolumn{3}{|c|}{ Correlations } \\
\hline pH & -0.233 & 0.437 & 0.125 & -0.588 & 0.675 & 0.169 \\
\hline $\mathrm{P}_{\mathrm{TE}}$ & -0.362 & 0.031 & -0.064 & -0.912 & 0.048 & -0.086 \\
\hline $\mathrm{P}_{\text {Total }}$ & -0.371 & -0.013 & -0.069 & -0.936 & -0.020 & -0.093 \\
\hline TRB & -0.364 & -0.048 & 0.170 & -0.917 & -0.075 & 0.230 \\
\hline$N$ & -0.283 & 0.198 & -0.414 & -0.713 & 0.305 & -0.561 \\
\hline C & -0.140 & 0.303 & -0.562 & -0.353 & 0.467 & -0.762 \\
\hline $\mathrm{CN}$ & 0.300 & 0.227 & -0.324 & 0.757 & 0.350 & -0.439 \\
\hline Al & 0.085 & -0.450 & -0.146 & 0.214 & -0.695 & -0.197 \\
\hline SB & -0.330 & 0.162 & 0.096 & -0.833 & 0.249 & 0.131 \\
\hline ECEC & -0.348 & -0.139 & 0.004 & -0.878 & -0.215 & 0.006 \\
\hline Sand & 0.217 & 0.411 & 0.214 & 0.548 & 0.634 & 0.290 \\
\hline Clay & -0.092 & -0.432 & -0.378 & -0.233 & -0.666 & -0.512 \\
\hline INDEX & -0.249 & -0.140 & 0.369 & -0.628 & -0.216 & 0.500 \\
\hline
\end{tabular}

Fig. 16. Principal coordinates analyses for soil variables in this study. 
is the absence of political barriers. Although the Amazon region was covered by several soil profiles in the RADAMBRASIL, their sampling was limited by the Brazilian border. Here we aimed to expand soil knowledge to other Amazonian countries in a comparable, methodologically consistent way. With regard to the soil information per se, RADAMBRASIL was a much larger study, and often has incomplete profile data and the cohort of analysis can vary slightly from on set of profiles to another. Also, RADAM's data comes from individual profiles, analyzed by soil horizon, which often makes comparisons between sites difficult given the natural vertical variations among different soil types (see Quesada et al., 2009a, for examples of such vertical variations). In that respect, the dataset used here is more consistent, all soils where sampled following a strict protocol, and divided in standardized depths allowing direct comparisons between areas. Our analysis methods are also standardized and fully comparable across all sites.

Finally, our dataset introduces important features which were not contemplated in the RADAM-BRASIL study, such as an appraisal of soil physical quality, soil weathering index, complete soil phosphorus fractionations, and nitrogen isotopic ratio.

\subsection{Distribution of soil nutrients across the soil age gradient}

The variation in phosphorus concentrations across the pedogenic gradient found in this work (Fig. 3a) is similar to the observations made in early chronosequence studies (Walker and Adams, 1958, 1959; Dahnke et al., 1964; Westin and de Brito, 1969; Smeck, 1973; Walker and Syers, 1976) as well as for results summarised in more recent reviews (Cross and Schlesinger, 1995; Johnson et al., 2003). In this study $\mathrm{P}_{\mathrm{T}}$ varied with pedogenic development, with the lowest $\mathrm{P}$ values found in the older soils while the highest values were found in young to intermediate age soils. $\mathrm{P}_{\mathrm{T}}$ increased from the youngest to intermediate age soils after which it declined. Nevertheless, levels attained in the youngest soils were still much higher than those found in the older soils. Throughout soil and ecosystem evolution, changes in soil fertility and nutrient cycling are expected to occur with soil phosphorus supply being considered the ultimate driver (Walker and Adams, 1958, 1959; Smeck, 1973, 1985; Walker and Syers, 1976). As soil phosphorus is almost exclusively supplied by parent material, $\mathrm{P}_{\mathrm{T}}$ declines as soil development proceeds due to processes such as loss of dissolved organic and inorganic $\mathrm{P}$, precipitation of insoluble or physically protected $\mathrm{P}$, loss of soil mass and permanent occlusion within soil minerals. Similarly to $\mathrm{P}$, other elements such as soil bases are lost by leaching or via loss of soil mass during the weathering process (Walker and Syers, 1976).

Soils with low pedogenetic development (i.e. Leptosols, Gleysols and Fluvisols), have their $\mathrm{P}$ pools dependent on the rate of weathering of their primary and secondary minerals with $\mathrm{P}$ generally present as apatite in the early phases and, some time after, as calcium phosphates. Consequently, $\mathrm{P}$ in labile forms is governed by the weathering of these minerals, which is strongly controlled by soil $\mathrm{pH}$. At $\mathrm{pH}$ values above 7, $\mathrm{P}$ solubility mostly come from Ca phosphates and apatites with solubility increasing as soil $\mathrm{pH}$ decreases. For large amounts of $\mathrm{P}$ to be circulating within the system, it is thus necessary that a soil has experienced a considerable time with a pH favourable to apatite dissolution (Smeck, 1973, 1985). Also, the mineral matrix of very young soils is often dominated by coarse particles which must first be weathered away to increase mineral surface area and allow nutrient release (Uehara and Gillman, 1981). Organic P accumulation also depends on a high supply of inorganic P (McGill and Cole, 1981). Therefore, the time by which the younger substrates have been exposed to weathering determines the amount of $\mathrm{P}$ that is accumulated throughout the weathering process.

The higher $\mathrm{P}_{\mathrm{TE}}$ of the intermediate soil orders probably reflects and ongoing transformations of the soil $\mathrm{P}$ pools. Once $\mathrm{P}$ has been released through mineral weathering at high rates, organic $\mathrm{P}$ and non-occluded forms of $\mathrm{P}$ tend to accumulate, and will continue to do so until the apatite content of the soil has fallen to such a low level that the P release from apatite is balanced by plant use, leaching and formation of residual P. The reason for organic phosphorus accumulation in the soil at this stage is that organic $\mathrm{P}$ mineralization depends on phosphatase enzymes and the rate of mineralization is controlled by end product supply (McGill and Cole, 1981). Once apatite $P$ has weathered from the system, the residual $\mathrm{P}$ pools start to grow at the expense of organic and non-occluded forms with $\mathrm{P}$ in solution governed principally by the solubility of iron, aluminium and calcium phosphates (Smeck, 1973, 1985).

As a soil further evolves, the entire phosphorus pool continues to decline (Fig. 3a) and calcium phosphates disappear or are extremely reduced to not more than trace amounts. $\mathrm{P}$ solubility becomes dependent on $\mathrm{Fe}$ and $\mathrm{Al}$ phosphates which become less and less soluble as $\mathrm{pH}$ decreases. Also at this stage more than half of the total $\mathrm{P}$ is found in residual forms (Fig. 7) which might only turnover on geological time scales.

$I_{\mathrm{E}}$ levels are controlled by similar general processes that govern total $\mathrm{P}$ losses and are particularly sensitive to changes in soil $\mathrm{pH}$. The weathering of silicate minerals depends largely on the process of hydrolysis, or in the activity of ionised water. In general, the $\mathrm{H}+$ ions replace the metal cations in the silicate lattice and the $\mathrm{OH}-$ ions combine with them to form soluble products which may be leached from the system. Calcium and sodium are the most mobile metals being easily weathered and precipitated, while magnesium and potassium are equally mobile but they tend to recombine to form clay minerals. Aluminium and ferric iron tend to remain as residual product of weathering usually as sesquioxides (Thomas, 1974). Therefore, throughout 
soil evolution, the most mobile elements will be made soluble and moved in higher proportions from the weathering sites with the less mobile elements remaining in solution for short periods where some may be subsequently lost or, alternatively, immobilised as part of new clay minerals. Aluminium can both represent both the final stage of this process in the form of sesquioxides or can contribute significantly to $I_{\mathrm{E}}$ when the weathering of $\mathrm{Al}$ interlayered minerals is taking place. The latter possibility seems to be occurring in the young-intermediate age soils in this study (Fig. 3d). Nevertheless, the actual balance between exchangeable bases and exchangeable aluminium in a soil (Fig. $3 \mathrm{c}$ and d) will depend strongly on the quality of parent material and its mineral assemblage. On the other hand, $I_{\mathrm{E}}$ is mostly governed by level of alteration and pedogenic development.

\subsection{Chemical and physical properties of Amazonian soils}

\subsubsection{Cations and soil reaction}

Figure 4 shows that extremely low and extremely high levels of exchangeable cations are not unusual for Amazon forest soils, but the occurrence of a high $I_{\mathrm{E}}$ levels in some of these soils suggests that for many of our study sites active mineral weathering is still occurring. High levels of exchangeable bases are released through weathering and for many sites extremely high values of $[\mathrm{Al}]_{\mathrm{E}}$ were measured, sometimes co-existing with relatively high levels of base cations. Overall, these high $[\mathrm{Al}]_{\mathrm{E}}$ indicate that for a many soils in this study, the product of active weathering is currently Al. Similar results have been reported before in the Amazon region by Marques et al. (2002). They suggested that the occurrence of such high $\mathrm{Al}$ availability may be related to weathering of Al bearing minerals such as vermiculite and smectite, which are common to the region (Marques et al., 2002; Lima et al., 2006). Such minerals have $\mathrm{Al}$ in the mineral interlayers which are in an interchangeable form. Nevertheless, it seems unlikely that such high Al levels are entirely active as plants on that region rarely show any sign of Al toxicity (Marques et al., 2002).

Changes in soil pH (Fig. 5) are a fundamental part of soil's evolutionary process and an intrinsic process governing changes in $I_{\mathrm{E}}$. In a simplistic way, as weathering occurs, very fine grained clay mineral particles are formed at the expense of coarse grained minerals. This process increases mineral specific surface area and thus the potential rate of nutrient release. As weathering proceeds, mineral dominance will change from primary and 2:1 silicate minerals to 1:1 minerals, and during such changes, soil permanent charges will be lost and variable charges tend to decrease. With the reduction in surface charge density, soils experience base cation leaching and after some time, aluminium release from 1:1 minerals starts to dominate, with the hydrolysis of $\mathrm{Al}$ resulting in release of $\mathrm{H}+$ to soil solution constantly lowering the $\mathrm{pH}$
(Uehara and Gillman, 1981). When soils are young, $\mathrm{pH}$ is higher as a result of the release of base cations which maintain $\mathrm{Al}$ in negligible levels. Considering that all other influencing factors are equal, as soils get older $\mathrm{Al}$ remains in mineral form and its hydrolysis influences $\mathrm{pH}$. However when interlayered $\mathrm{Al}$ bearing minerals dominate the mineral matrix, $\mathrm{Al}$ will be the main product of weathering, resulting in lower $\mathrm{pH}$ even in young soils. Thus parent material; pedogenic development and mineral assemblage all have important influences over soil $\mathrm{pH}$.

\subsubsection{Soil phosphorus}

Figure 6 shows a broad range of variation in P pools across Amazonia. Such a wide range of phosphorus and cation contents reflects the large diversity of parent materials and soil evolutionary stages, and should have important implications for plant and ecosystem functioning. Along the decline in total phosphorus throughout soil development, the Ca-P $(\mathrm{HCl}$ fraction) tended to disappear as soils become older with organic forms of $\mathrm{P}$ also declining sharply from young to older soils (Fig. 9b). Nevertheless, the importance of organic P for the soil phosphorus economy should increases as a soil gets older. This is because available $\mathrm{P}$ forms also decline with organic $\mathrm{P}$ becoming the largest fraction of total extractable pool along with inorganic $\mathrm{NaOH}$ extracted $\mathrm{P}$ (Walker and Syers, 1976). The residual pool tended to account for most of total $\mathrm{P}$ in old, intensively weathered soils but was also found to be at relatively high levels for some younger soils (Fig. 7). This may occur because the bulk of the residual pool may include recalcitrant, strongly adsorbed phosphorus, physically protected or occluded $\mathrm{P}$ in minerals structurally devoid of $\mathrm{P}$ (Smeck, 1985; Cross and Schlesinger, 1995). This is in addition to any remaining highly insoluble $P$ stored in soil minerals (Syers et al., 1967), with the balance between the different compounds depending on soil age.

It is noteworthy to mention that Arenosols and Podzols have very different $\mathrm{P}$ distribution patterns as compared to other soil groups (Fig. 7). Most of the $\mathrm{P}$ found in these soils is in readily available forms, but $\mathrm{P}_{\mathrm{T}}$ being rather small. Such low levels probably reflect the chemical paucity of parent material (mostly quartz), low surface charge density and its low adsorption capacity. Therefore, most of the P supply in the Amazonian sandy soils must come from continually cycling organic sources, similar to the terminal steady state suggested by Walker and Syers (1976).

Changes in soil $\mathrm{P}$ content and distribution across different soil types and weathering degrees have previously been reported widely in the literature. For instance, Dahnke et al. (1964) reported that phosphorus forms changed across a soil development gradient in El Salvador, with $\mathrm{P}_{\mathrm{T}}$ decreasing along the age gradient as was also the case for all other forms examined with the exception of residual $\mathrm{P}$ which increased. Walker (1964) reviewed information on P losses and transformations across soil sequences with similar conclusions, 
while Westin and de Brito (1969) analysed $\mathrm{P}$ forms in a range of soil types in Venezuela, concluding that $\mathrm{P}_{\mathrm{T}}, \mathrm{Ca}-$ $\mathrm{P}, \mathrm{P}_{\mathrm{ORG}}$ and $\mathrm{P}$ associated to secondary minerals all decreased as weathering degree increased. Nevertheless, it was Walker and Syers (1976) who conceptualized the model involved in changes of $\mathrm{P}$ pools across soil age gradients. The authors suggested that the proportion of $\mathrm{P}$ in its different forms should vary along a gradient of weathering intensity; $\mathrm{P}$ in very young soils should be found mainly in primary minerals as apatite, while intermediate age soils would have mainly $\mathrm{P}$ forms adsorbed to secondary minerals and organic P. Highly weathered soils were suggested to have mostly low turnover and recalcitrant $\mathrm{P}$ forms such as residual, and both organic and inorganic $\mathrm{NaOH}$ fractions, whilst soils in a terminal weathering stage would have low $\mathrm{P}$ supply derived mainly from residual and organic forms, termed by Walker and Syers (1976) as the "terminal steady state". Furthermore, Tiessen et al. (1984) fractionated P forms in 168 benchmark soils spanning eight US Soil Taxonomy orders and concluded that $\mathrm{P}$ forms were related to soil orders. More recent studies analysing $\mathrm{P}$ fractions from standard Hedley fractionations (Hedley et al., 1982), supported the notion that $\mathrm{P}$ forms changed during soil development (Smeck, 1985; Stewart and Tiessen, 1987; Cross and Schlesinger, 1995).

The results found in this study also support the idea of $\mathrm{P}$ pools changing dynamically along soil age gradients and further indicate that $\mathrm{P}$ forms also vary in association with lower classification levels. These intergrades within soil types, associated with slightly different levels of weathering also resulted in differentiation of $\mathrm{P}$ pools and often other elements. For instance, Geric Ferralsols which are thought to be the most weathered group inside Ferralsols, had 0.14 more $\mathrm{P}$ in residual form and less hydroxide $\mathrm{P}$ than the Geric Acric Ferralsols where traces of clay accumulation still remain. However, Cambisols were the soil group with largest variation within their lower classification levels, with $\mathrm{P}$ as well as other nutrients varying widely following the weathering sequence Orthoeutric $>$ Hyperdystric $>$ Hyperdystric Alumic. Such wide variation in Cambisols is likely to be associated with different levels of surface soil weathering and maybe differences in parent material which, in the case of Cambisols, can exert a large influence on soil properties (Buol et al., 1980).

The variation in P pools along age gradients is further supported by the relationship between the weathering index $\Sigma_{\mathrm{RB}}$ and $\mathrm{P}_{\mathrm{T}}$ (Fig. 8). As $\Sigma_{\mathrm{RB}}$ provides a chemical estimation of weatherable minerals, its values should reflect the continuum of weathering extent (Herbillon, 1989; Delvaux et al., 1989) with high $\Sigma_{\mathrm{RB}}$ implying an abundance of easily weatherable minerals which may become a source of $\mathrm{P}$ and other elements for young-intermediate age soils. On the other hand, more intensively weathered soils with low $\Sigma_{\mathrm{RB}}$ must base their $\mathrm{P}$ economy on recycling $\mathrm{P}$ among the various fractions, resulting in tight nutrient cycles, both within the soil and the vegetation above.
Another side of soil $\mathrm{P}$ availability is the proportion of total $\mathrm{P}$ that is likely to cycle through biological processes and Fig. 9a shows how the "available" $\left(\mathrm{P}_{\mathrm{TE}}\right)$ fraction relates to $\mathrm{P}_{\mathrm{T}}$. This shows that the available proportion changes markedly across the various soil types, reflecting different soil evolutionary stages and being influenced by contrasting processes like mineral $\mathrm{P}$ fixation, depletion of $\mathrm{P}$ fixing sites (sands), $P$ release through active mineral weathering and differences in organic P mineralization. Nevertheless, the actual $\mathrm{P}$ forms that make the available (or labile) $\mathrm{P}$ pool are still a matter of debate. Cross and Schlesinger (1995) and Johnson et al. (2003) suggest that resin and bicarbonate fractions (organic + inorganic) are subject to rapid turnover in the soil, and are thus the most likely contributors to plant available $\mathrm{P}$, this also being the general consensus in the literature. Nevertheless, there is increasing evidence that more recalcitrant forms of $\mathrm{P}$ such as hydroxide and hydrochloric can contribute to $\mathrm{P}$ economy of the vegetation. For example, $\mathrm{Ki}$ tayama et al. (2000), studying litterfall and P use efficiencies on tropical vegetation in Borneo, reported that the summing of resin, bicarbonate (organic + inorganic), Na hydroxide (organic + inorganic) and hydrochloric forms (therefore total extractable $\mathrm{P}$ ) provided the best estimation of $\mathrm{P}$ availability for plants, also concluding that the $\mathrm{HCl}$ fraction (Ca-P) was a significant source of phosphorus. Likewise, Quesada et al. (2009b) showed that the ability of P pools to explain variations in forest wood production in Amazonia increased with the inclusion of more stable, slow turnover forms such as the total P pool and total extractable P. In addition, Tiessen et al. (1984), Magid et al. (1996) and Frossard et al. (2000) all report that both $\mathrm{NaHCO}_{3}$ and $\mathrm{NaOH}$ organic $\mathrm{P}$ fractions have a significant contribution to plant uptake, with its importance increasing as $\mathrm{P}$ deficiency increases (Nziguheba and Bünemann 2005). A large number of works also support evidence of $\mathrm{P}$ depletion from hydrochloric and hydroxide fractions (Jung and Claassen, 1986, 1989; Gahoonia et al., 1992; Hedley et al., 1994; Saleque and Kirk, 1995; Hinsinger and Gilkes, 1996; Trolove et al., 1996; Zoysa et al., 1997, 1998, 1999; Bertrand et al., 1999), and several other studies report $\mathrm{P}$ depletion in organic and inorganic hydroxide pools after cultivation (Adepetu and Corey, 1976; Sattell and Morris, 1992; Guo and Yost, 1998; Nziguheba and Bünemann, 2005). Other studies did not result in a clear picture (Friessen et al., 1997) or reported mostly the uptake of readily available forms of $\mathrm{P}$ such as resin and bicarbonate fractions (Gahoonia and Nielsen, 1992; Crews, 1996). It is however very likely that the utilization of non-immediately available forms of P should vary depending on pool sizes, phosphorus availability and demand. Stable, recalcitrant $P$ pools, along with organic $\mathrm{P}$, may become practically the unique sources of $\mathrm{P}$ in intensively weathered soils. A comprehensive view of $P$ transformations in the soil is given by Tiessen et al. (1984), suggesting that solution $\mathrm{P}$ is in dynamic equilibrium with more labile fractions such as resin and inorganic bicarbonate fractions, with more stable, slow turnover fractions such as 
hydroxide and hydrochloric acting as a sink as well as long term reservoirs of inorganic $\mathrm{P}$ which are capable of buffering more labile $\mathrm{P}$ forms (Murrman and Peech, 1969). Movements of $\mathrm{P}$ out of slow turnover buffer fractions are given by dissolution equilibria (Hinsinger, 2001); meaning that once plant uptake depletes $\mathrm{P}$ in solution a chemical gradient is created and releases $\mathrm{P}$ from buffer fractions. As $\mathrm{P}$ depleted soils depend strongly on slow turnover fractions such as organic and inorganic hydroxide, $\mathrm{P}$ uptake may result in a very steep chemical gradient which supports the idea that the availability of individual fractions may vary with general $\mathrm{P}$ supply. However, it is noteworthy that concentrations of $\mathrm{P}$ ions in solution are not simply governed by precipitation-dissolution equilibrium but by adsorption/desorption onto various soil constituents (Hinsinger, 2001). Organic P may perform similar functions through biochemical mineralization processes (McGill and Cole, 1981) with Tiessen et al. (1984) suggesting that both larger organic fractions (bicarbonate and hydroxide) undergo rapid turnover. However, organic $\mathrm{P}$ forms in bicarbonate are thought to be easily mineralizable while hydroxide forms tend to be relatively more stable (Tiessen et al., 1984). In any case, soil P availability should depend not only on pool sizes but also on solution concentrations, net rates of desorption/release, duration of $\mathrm{P}$ demand and microbial processes (Johnson et al., 2003).

Changes occurring on organic $\mathrm{P}$ forms throughout weathering stages are another component of variation in total extractable P. Figure $9 \mathrm{~b}$ shows that the organic proportion of the total extractable pool varies markedly, with older soils having relatively lower fractions in the total extractable pool, but with organic $\mathrm{P}$ fractions constituting as much as 0.74 of $\mathrm{P}_{\mathrm{TE}}$ in young and intermediate aged soils. Probably the principal mechanism governing the accumulation and losses of organic $\mathrm{P}$ involves the observation that mineralization of organic phosphorus can occur independently of carbon mineralization. McGill and Cole (1981) demonstrated that this independent mineralization of $\mathrm{P}_{\mathrm{ORG}}$ occurs through enzymatic hydrolysis of phosphate esters, with rates supplementing that through carbon oxidation, also suggesting that mineralization of $\mathrm{P}_{\mathrm{ORG}}$ is catalysed by the enzyme phosphohydrolase, which is excreted by plant roots and microorganisms. They also indicated that the synthesis of phosphohydrolases is controlled by end product supply (in that case the available content of $\mathrm{P}$ in the soil) thus being produced in response to $\mathrm{P}$ needs and repressed by an adequate $\mathrm{P}$ supply. Therefore, as long the supply of labile $\mathrm{P}$ is high or at least adequate for plant requirements, organic $P$ mineralization would be repressed and organic $\mathrm{P}$ would be expected to accumulate in soil. Nevertheless, even soils with a high initial P supply will reach a point where inorganic $\mathrm{P}$ becomes reduced as a result of leaching and progressive accumulation of $\mathrm{P}$ into unavailable forms. As $\mathrm{P}$ is continually removed from soils, there will come a point where low phosphorus supply should induce phosphohydrolase synthesis which would result in mineralization of $\mathrm{P}_{\mathrm{ORG}}$ increasing progressively. Williams and
Walker (1969) indicated that organic P content attains maximum values at the point when all primary $\mathrm{P}$ is released by weathering. Beyond that point enzymatic hydrolysis of $\mathrm{P}_{\mathrm{ORG}}$ increases and organic P pools start to decrease.

\subsubsection{Carbon and nitrogen}

Soil organic matter content is a function of relative rates of primary production and mineralization (Smeck, 1985), but is also influenced by other soil and environmental properties that control losses and accumulation of organic matter, such as general soil fertility, soil texture, mineralogy assemblage, moisture regime and climate. At different stages of soil evolution, organic matter contents should equilibrate at certain levels and remain essentially constant due to similar rates of production and mineralization. Soil carbon and nitrogen were observed to decrease along a gradient of soil age and evolution which may reflect a gradient of soil specific surface area, surface charge density and organic matter adsorption (Uehara and Gillman, 1981). At the most weathered end of the spectrum $[\mathrm{C}]$ seems to be controlled by accumulation of recalcitrant forms of carbon and nitrogen in soils, most likely produced as a result of P deficiencies. Examples of such compounds are the humic and fulvic acids that give colour to black water rivers in the regions where such highly weathered soils dominate (Herrera et al., 1978; Gaillardet et al., 1997). Another likely contribution to organic matter build-up in these soils may be the concentrations of amorphous iron and $\mathrm{Al}$ oxides which have great affinity to organic matter compounds (Mikutta et al., 2006). Other environmental and edaphic controls were also observed, as the higher [C] found could be related to moisture regime such as seasonal saturation and impediments to drainage or to soil physical structure and mineralogy assemblage such as in soils with andic, nitic and cambic properties.

Adding to the discussion of phosphorus influences on the nitrogen cycle in tropical forest soils (Vitousek et al., 2002), nitrogen cycling, as evidenced by patterns of $\delta^{15} \mathrm{~N}$ enrichment and depletion, varied in a strongly non-linear way when examined as a function of total extractable P (Fig. 11). This relationship was even clearer when only the total inorganic phosphorus fraction was plotted against $\delta^{15} \mathrm{~N}$ but for consistency with other diagrams $\mathrm{P}_{\mathrm{TE}}$ has been used as the predictor variable. We interpret this relationship as follows: On the basis of simple mass balance principles and as evidenced by $\delta^{15} \mathrm{~N}$ modelling studies (Brenner et al., 2001; Houlton et al., 2006) if the nitrogen cycle of an ecosystem is in a state where losses exceed inputs, then any fractionations occurring within that ecosystem will be expressed and for $\delta^{15} \mathrm{~N}$ in soils, internal cycling processes tend to discriminate against $\delta^{15} \mathrm{~N}$. Thus the excess $\delta^{15} \mathrm{~N}$ leaving the system (as leachate or $\mathrm{NO}_{\mathrm{x}}$ fluxes) is depleted and $\delta^{15} \mathrm{~N}$ of the nitrogen remaining in the ecosystem becomes enriched (Högberg, 1997; Martinelli et al., 1999; Houlton et al., 2006). But this tendency for a "leaky" system to become enriched should 
continuously be being counteracted by $\delta^{15} \mathrm{~N}$ inputs of inorganic nitrogen through precipitation inputs which are typically around $0 \%$ (Heaton, 1987; Wania et al., 2002). Also noting that although Dissolved Organic Nitrogen (DON) entering an ecosystem through precipitation may be substantially enriched above $0 \%$, this is of no consequence to the argument that follows as the DON probably originated from the same ecosystem (or somewhere nearby at least), then the more enriched above precipitation inorganic $\mathrm{N}$ inputs the $\delta^{15} \mathrm{~N}$ of the ecosystem becomes, the greater this counteracting precipitation effect should be in relative terms. In interpreting Fig. 11 then, rather than taking the variations in measured $\delta^{15} \mathrm{~N}$ to reflect some sort of "current day" relationship as is sometimes done (e.g. Houlton et al., 2006; Nardoto et al., 2008) one can interpret the gradual increase in $\delta^{15} \mathrm{~N}$ as soil $\mathrm{P}$ declines, as reflecting accumulated losses of nitrogen from Amazonian forest ecosystems which have occurred because even those forests of the highest soil phosphorus status still appear to have their productivity limited by phosphorus (Quesada, 2009b).

That nitrogen is in excess for most tropical ecosystems (except forests growing on white sands) is, of course, already widely accepted (Vitousek and Sanford, 1986; Matson and Vitousek, 1987; Keller and Reiners, 1994; Matson et al., 1999; Martinelli et al., 1999; Schwendenmann and Veldkamp, 2005), but from our pedogenic viewpoint, however, we also argue that as these losses continue to occur, the soil C:N ratio of the soils should also gradually increase (Fig. 12c) until a critical threshold around $30 \mathrm{mg} \mathrm{kg}^{-1}$ is reached. Beyond this, the system once again becomes more closed with respect to the nitrogen cycle, and thus enrichment ceases and the soil $\delta^{15} \mathrm{~N}$ tends back towards the isotopic composition of the input precipitation (ca. 0\%o). The white sands forests of Amazonia have long been known to have relatively depleted $\delta^{15} \mathrm{~N}$ (Martinelli et al., 1999), and a large fraction of the sites on the "downside" of the curve are indeed sandy soils. But importantly, there are also other soils types with similar low P levels on the low side of the "breakpoint" (Fig. 11). This suggests that rather than just being a soil type effect, extremely low soil P concentrations may itself be the cause of these soils having strongly depleted $\delta^{15} \mathrm{~N}$, with the phosphorus shortage itself leading to a lower rate of nitrogen return to soil. That is to say (in simplistic terms) at very low $\mathrm{P}$ availability, the forests actually become nitrogen limited.

This is hypothesised to be a consequence of constrained decomposition rates as low rates of soil phosphorus availability have been reported to increase lignin production (Coley et al., 1985; Hirobe et al., 2004) and also because phosphorus availability seems to be the most important factor affecting the rate of decomposition in tropical forests (Vitousek et al., 1994; Aerts, 1997; Austin and Vitousek, 2000; Hirobe et al., 2004). High rates of nutrient resorption before leaf shedding may also result in a higher relative concentration of lignin in litter for vegetation on low phosphorus soils (Kitayama et al.,
2004). This effect would result in even stronger constraints to $\mathrm{N}$ mineralization through decomposition. In addition to the effects of lignin on litter decomposition per se, large concentrations of lignin compounds in the soil may themselves reduce nitrogen availability as nitrogen is incorporated into the lignin fraction of the litter during humification, remaining strongly bound to it until total lignin degradation is achieved (Stevenson, 1994; Berg, 2000; Schmidt-Rohr et al., 2004; Olk et al., 2006). Moreover, high levels of tannins and lignin seem to inhibit enzymes involved in nitrogen mineralization to a greater extent than enzymes involved in phosphorus mineralization (Kraus et al., 2003; Nierop et al., 2006; Joanisee et al., 2007).

Our interpretation of the observed variations in soil C:N ratios thus suggests that to a large extent they are a simple reflection of changes in soil $\mathrm{P}$ status as tropical forest ecosystems age. This implies that for tropical forest soils the meaning of C:N ratios as potential "limiting factors" may be more apparent than real, at least for most of the soils in this study. They most likely reflect ecosystem age and associated differences in decomposability of litter material, which should have different concentrations of lignin and other defence compounds across the $\mathrm{P}$ availability spectrum, with this resulting in differences in decomposability, and in a build up of recalcitrant carbon in relation to nitrogen on the most infertile sites. The relationship between $\mathrm{P}$ and $\delta^{15} \mathrm{~N}$ also gives insights into nitrogen fixation in the studied forests. As nitrogen seems to generally be in excess to phosphorus supply, it seems unlikely that $\mathrm{N}_{2}$ fixation by legumes could be an advantage (Vitousek et al., 2002). As nitrogen supplies seem not to be constrained for most of Amazonia, $\mathrm{N}_{2}$-fixers should be able to maintain their $\mathrm{N}$ demanding life style without having to fix nitrogen from the atmosphere. This is in accordance with the observation that plants capable of $\mathrm{N}_{2}$ fixation rarely do so in Amazonia (Vitousek et al., 2002; Nardoto et al., 2008) - this despite recent work from Houlton et al. (2008) that has suggested a different view.

\subsubsection{Soil physical properties}

Similar to the situation for soil fertility, soil physical properties were observed to vary according to the distribution of major geological formations and were associated with the degree of soil weathering and pedogenic development. These relationships between geomorphology, weathering degree and soil physical properties are evidenced by the relationship between $\Sigma_{\mathrm{RB}}$ and $\Pi$ (Fig. 14). High $\Pi$ were almost always accompanied by elevated $\Sigma_{\mathrm{RB}}$ indicating that a major abundance of primary minerals is indeed related to poor physical conditions. Conversely, soils with the lowest $\Pi$ all had low $\Sigma_{\mathrm{RB}}$ suggesting that soils likely to impose few physical constraints have also weathered away almost all their primary minerals.

Thus, one could logically expect that nutrient levels and physical properties would be inter-related. This occurs 
because soil fertility and the development of physical characteristics are both affected by the same conditioning factors, such as geology and geomorphology and pedogenic development. For example, landscape position and topography greatly influence soil physical and chemical properties, often dictating the depth in which active mineral weathering occurs. On steep slopes, erosion continually reduces soil thickness, placing the weathering zone near the surface, thus rejuvenating the soil and increasing its capacity of exchange nutrients. However, in addition to this effect on mineral weathering and element availability, active erosion brings physical conditions common to deep, poorly developed horizons to a closer proximity to the soil surface, thus giving rise to compacted, poorly aggregated and dense horizons. On the other hand flatter landscapes on old geologic surfaces tend to favour deep soil weathering and exclusion of rock weathering as a source of nutrients. Consequently erosion rates are generally much smaller, allowing soil surface horizons to endure intensive weathering. This results in deeper, better drained soils with much more favourable physical structure but extensively leached and thus extremely low in both total and available nutrients.

\subsubsection{Principal component analysis}

Results from the principal component analysis (Fig. 16) summarize the general patterns of soil properties across Amazonia. The first axis represents the soil age gradient and its associated variations in fertility. It stands as a primary gradient and interactions with other axis should determine the distribution and separation of the study sites. For instance, the sand - clay gradient in axis- 2 complements axis- 1 in creating a clear gradient of particle size and fertility. Another important interacting factor is $[\mathrm{Al}]_{\mathrm{E}}$, further separating the study sites in the sand-clay gradient by concentrating together low fertility sites with [Al $]_{\mathrm{E}}$ typical of old soils rich in sesquioxides, whereas sites with high $[\mathrm{Al}]_{\mathrm{E}}$ are further separated by their higher phosphorus levels which should come from the active weathering of $\mathrm{Al}$ bearing minerals in these younger soils. The high soil $\mathrm{pH}$, absence of $\mathrm{Al}$, together with very high $\mathrm{P}$ and bases levels further separates another group of soils, all of which occupy lower levels in the age gradient. The third axis is dominated by properties reflecting interactions with age and fertility such as $\Pi$, as well as [C] and $[\mathrm{N}]$ which, along with $\mathrm{C}: \mathrm{N}$ ratio, seem to be influenced by soil $\mathrm{P}$ supply and possibly by the abundance and type of primary and secondary minerals. Therefore, weathering status, age and shape of geologic surfaces, and quality of parent material can be considered the main determinants for both the supply of nutrients and physical properties, with phosphorus availability, soil texture, $[\mathrm{Al}]_{\mathrm{E}}, \Sigma_{\mathrm{RB}}$ and $\Pi$ as the soil properties that most effectively discriminated the different study sites.
Acknowledgements. Carlos A. Quesada was funded by a scholarship from the School of Geography, University of Leeds. The final stages of data analysis and manuscript preparation were funded by the Gordon and Betty Moore Foundation, now supporting the RAINFOR project (www.rainfor.org).

Edited by: P. Meir

\section{References}

Adepetu, J. A. and Corey, R. B.: Organic phosphorus as a predictor of plant-available phosphorus in soils of Southern Nigeria, Soil Sci., 122, 159-164, 1976.

Aerts, R.: Climate, leaf litter chemistry and leaf litter decomposition in terrestrial ecosystems: a triangular relationship, Oikos, 79, 439-449, 1997.

Allen, B. L. and Fanning, D. S.: Composition and soil genesis, in: Pedogenesis and Soil Taxonomy: Concepts and Interactions, edited by: Wilding, L. P., Smeck, N. E., and Hall, G. F., Elsevier, 141-192, 1988.

Austin, A. T. and Vitousek, P. M.: Precipitation, decomposition and litter decomposability of Metrosideros polymorpha in native forests on Hawai'i, J. Ecol., 88, 129-138, 2000.

Berg, B.: Litter decomposition and organic matter turnover in northern forest soils, Forest Ecol. Manag. 133, 13-22, 2000.

Bertrand, I., Hinsinger, P., Jaillard, B., and Arvieu, J. C.: Dynamics of phosphorus in the rizhosphere of maize and rape grown on synthetic, phosphated calcite and goethite, Plant Soil, 211, 111119, 1999.

Brenner, D. L., Amundson, R., Baisden, W. T., Kendall, C., and Harden, J.: Soil $\mathrm{N}$ and ${ }^{15} \mathrm{~N}$ variation with time in a California annual grassland ecosystem, Geochim. Cosmochim. Ac., 65, 4171-4186, 2001.

Buol, S. W., Hole, F. D., and McCracken, R. J.: Soil genesis and classification, The Iowa State University Press, Ames, Iowa, 1980.

Coley, P. D., Bryant, J. P., and Chapin, F. S. I.: Resource availability and plant antiherbivore defense, Science, 230, 895-899, 1985.

Crews, T. E.: The supply of phosphorus from native, inorganic phosphorus pools in continuously cultivated Mexican agroecosystems, Agr. Ecosyst. Environ., 57, 197-208, 1996.

Crews, T. E., Kitayama, K., Fownes, J. H., Riley, R. H., Herbert, D. A., Mueller-Dombois, D., and Vitousek, P. M.: Changes in soil phosphorus fractions and ecosystem dynamics across a long chronosequence in Hawaii, Ecology, 76, 1407-1424, 1995.

Cross, A. F. and Schlesinger, W. H.: A literature review and evaluation of the Hedly fractionation: Applications to the biogeochemical cycle of soil phosphorus in natural ecosystems, Geoderma, 64, 197-214, 1995.

Dahnke, W. C., Malcolm, J. C., and Mendez, M. E.: Phosphorus fractions in selected profiles of El Salvador as reflected in their development, Soil Sci., 98, 33-38, 1964.

Delvaux, B., Herbillon, A. J., and Vielvoye, L.: Characterization of a weathering sequence of soils derived from volcanic ash in Cameroon, Taxonomic, mineralogical and agronomic implications, Geoderma, 45, 375-388, 1989.

Driessen, P., Deckers, J., Spaargaren, O., and Nachtergaele, F.: Lecture notes on the major soils of the world, FAO, Rome, 35-37, 2001. 
Fittkau, E. J.: Esboço de uma divisão ecolôgica da região amazônica, Proc. Symp. Biol. Trop. Amaz., Florencia y Leticia, 1969, 363-372, 1971.

Fittkau, E. J., Irmler, U., Junt, W. J., Reis, F., and Schmidt, G. W.: Productivity, biomass and population dynamics in Amazonian water bodies, in: Tropical ecological systems, Trends in terrestrial and aquatic and research, edited by: Golley, G. B. and Medina, E., Springer, New York, Berlin, 289-311, 1975.

Friessen, D. K., Rao, I. M., Thomas, R. J., Oberson, A., and Sanz, J. I.: Phosphorus acquisition and cycling in crop and pasture systems in low fertility tropical soils, Plant Soil, 196, 289-294, 1997.

Frossard, E., Condron, L. M., Oberson, A., Sinaj, S., and Fardeau, J. C.: Processes governing phosphorus availability in temperate soils, J. Environ. Qual., 29, 15-23, 2000.

Gahoonia, T. S. and Nielsen, N. E.: The effects of root-induced $\mathrm{pH}$ changes on the depletion of inorganic and organic phosphorus in the rhizosphere, Plant Soil, 143, 185-191, 1992.

Gahoonia, T. S., Claassen, N., and Jungk, A.: Mobilization of residual phosphate of different phosphate fertilizers in relation to $\mathrm{pH}$ in the rhizosphere of ryegrass, Nutr. Cycl. Agroecosys., 33, 229237, 1992.

Gaillardet, J., Dupre, B., Allegre, C., and Negrel, P.: Chemical and physical denudation of the Amazon River Basin, Chem. Geol., 142, 141-173, 1997.

Gee, G. W. and Bauder, J. W.: Particle-size analysis, in: Methods in Soil Analysis, Part 1, Physical and Mineralogical Methods, edited by: Klute, A., American Society of Agronomy and Soil Science Society of America, Madison, Wisconsin, USA, 383409, 1986.

Guo, F. and Yost, R. S.: Partitioning soil phosphorus into three discrete pools of differing availability, Soil Sci., 163, 822-833, 1998.

Heaton, T. H. E.: ${ }^{15} \mathrm{~N} /{ }^{14} \mathrm{~N}$ ratios of nitrate and ammonium in rain at Pretoria, South Africa, Atmos. Environ., 21, 843-852, 1987.

Hedley, M. J., Kirk, G. J. R., and Santos, M. B.: Phosphorus efficiency and the forms of soil phosphorus utilized by upland rice cultivars, Plant Soil, 158, 53-62, 1994.

Hedley, M. J., Stewart, J. W. B., and Chauhan, B. S.: Changes in inorganic and organic soil phosphorus fractions induced by cultivation practices and by laboratory incubations, Soil Sci. Soc. Am. J., 46, 970-976, 1982.

Herbillon, A. J.: Chemical estimation of weatherable minerals present in the diagnostic horizons of low activity clay soils, 8th Int. Soil Classification Workshop 1986, Brazil, 39-48, 1989.

Herrera, R., Jordan, C. F., Klinge, H., and Medina, E.: Amazon ecosystems: Their structure and functioning with particular emphasis on nutrients, Interciencia, 3, 223-232, 1978.

Hinsinger, P.: Bioavailability of soil inorganic P in the rhizosphere as affected by root-induced chemical changes: a review, Plant Soil, 237, 173-195, 2001.

Hinsinger, P. and Gilkes, R. J.: Mobilization of phosphate from phosphate rock and alumina-sorbed phosphate by the roots of ryegrass and clover as related to rhizosphere $\mathrm{pH}$, Eur. J. Soil Sci., 47, 533-544, 1996.

Hirobe, M., Sabang, J., Bhatta, B. K., and Takeda, H.: Leaf-litter decomposition of 15 tree species in a lowland tropical rain forest in Sarawak: decomposition rates and the initial litter chemistry, J. Forest Res., 9, 341-346, 2004.
Högberg, P.: $15 \mathrm{~N}$ natural abundance in soil-plant systems, New Phytol., 137, 179-203, 1997.

Houlton, B. Z., Sigman, D. M., and Hedin, L. O.: Isotopic evidence for large gaseous nitrogen losses from tropical rainforests, Natl. Acad. Sci. USA, 103, 8745-8750, 2006.

Houlton, B. Z., Wang, Y.-P., Vitousek, P. M., and Field, C. B.: A unifying framework for dinitrogen fixation in the terrestrial biosphere, Nature, 454, 327-330, 2008.

Irion, G.: Soil infertility in the Amazonian rain forest, Naturwissenschaften, 65, 515-519, 1978.

IUSS Working Group WRB: World reference base for soil resources 2006: A framework for international classification, correlation and communication, World Soil Resources Report 103, FAO, Rome, 2006.

Jahn, R., Blume, H.-P., Asio, V. B., Spaargaren, O., and Schad, P.: Guidelines for soil description, FAO, Rome, 97, 2006.

Joanisse, G. D., Bradley, R. L., Preston, C. M., and Munson, A. D.: Soil enzyme inhibition by condensed litter tannins may drive ecosystem structure and processes: the case of Kalmia angustifolia, New Phytol., 175, 535-546, 2007.

Johnson, A. H., Frizano, J., and Vann, D. R.: Biogeochemical implications of labile phosphorus in forest soils determined by the Hedley fractionation procedure, Oecologia, 135, 487-499, 2003.

Jordan, C. F. and Herrera, R.: Tropical rain forests: are nutrients really critical?, Am. Nat., 117, 167-180, 1981.

Jungk, A. and Claassen, N.: Availability of phosphate and potassium as the result of interactions between root and soil in the rhizosphere, Z. Pflanz. Bodenkunde, 149, 411-427, 1986.

Jungk, A. and Claassen, N.: Availability in soil and acquisition by plants as the basis for phosphorus and potassium supply to plants, Z. Pflanz. Bodenkunde, 52, 151-157, 1989.

Keller, M. and Reiners, W. A.: Soil-atmosphere exchange of nitrous oxide, nitric oxide, and methane under secondary succession of pasture to forest in the Atlantic lowlands of Costa Rica, Global Biogeochem. Cy., 8, 399-409, 1994.

Kitayama, K., Suzuki, S., Hori, M., Takyu, M., Aiba, S.-I., MajalapLee, N., and Kikuzawa, K.: On the relationship between leaflitter lignin and net primary productivity in tropical rain forests, Oecologia, 140, 335-339, 2004.

Kitayama, K., Majalap-Lee, N., and Aiba, S.-I.: Soil phosphorus fractionation and phosphorus-use efficiencies of tropical rain forests along altitudinal gradients of Mount Kinabalu, Borneo, Oecologia, 123, 342-349, 2000.

Kraus, T. E., Dahlgren, R. A., and Zasoski, R. J.: Tannins in nutrient dynamics of forest ecosystems - a review, Plant Soil, 256, 41-66, 2003.

Kuo, S.: Phosphorus, in: Methods of Soil Analysis, Part 3, Chemical Methods edited by: Sparks, D. L., Page, A. L., Helmke, P. A., Loeppert, R. H., Soltanpour, P. N., Tabatabai, M. A., Johnston, C. T., and Summer, M. E., SSSA Book Series Number 5, Soil Science Society of America and American Society of Agronomy, Madison, Wisconsin, USA, 894-895, 1996.

Lambers, H., Raven, J. A., Shaver, G. R., and Smith, S. E.: Plant nutrient-acquisition strategies change with soil age, Trends Ecol. Evol., 23, 95-103, 2008.

Lemon, J. and Fellows, I.: concord: Concordance and reliability, R package version 1.4-9, http://cran.r-project.org/, last access: September 2008, 2007. 
Lima, H. N., Mello, J. W. V., Schaefer, C. E. G. R., Ker, J. C., and Lima, A. M. N.: Mineralogia e quimica de tres solos de uma topossequencia da bacia sedimentar do Alto Solimoes, Amazonia Ocidental, Revista Brasileira de Ciencia do Solo, 30, 59-68, 2006.

Magid, J., Tiessen, H. and Condron, L. M.: Dynamics of organic phosphorus in soils under natural and agricultural ecosystems, in: Humic Substances in Terrestrial Ecosystems, edited by: Piccolo, H., Elsevier, Amsterdam, 429-466, 1996.

Marques, J. J. G. S. M., Teixeira, W. G., Schulze, D. G., and Curi, N.: Mineralogy of soils with unusually high exchangeable Al from the western Amazon Region, Clay Miner., 37, 651-661, 2002.

Martinelli, L. A., Piccolo, M. C., Townsend, A. R., Vitousek, P. M., Cuevas, E., McDowell, W., Robertson, G. P., Santos, O. C., and Treseder, K.: Nitrogen stable isotopic composition of leaves and soil: Tropical versus temperate forests, Biogeochemistry, 46, 45-65, 1999.

Matson, P. A. and Vitousek, P. M.: Cross-ecosystem comparisons of soil nitrogen and nitrous oxide flux in tropical ecosystems, Global Biogeochem. Cy., 1, 163-170, 1987.

Matson, P. A., McDowell, W. H., Townsend, A. R., and Vitousek, P. M.: The globalization of $\mathrm{N}$ deposition: ecosystem consequences in tropical environments, Biogeochemistry, 46, 67-83, 1999.

McGill, W. B. and Cole, C. V.: Comparative aspects of cycling of organic $\mathrm{C}, \mathrm{N}$, and $\mathrm{P}$ through soil organic matter, Geoderma, 26, 267-286, 1981.

Mikutta, C., Lang, F., and Kaupenjohann, M.: Kinetics of phosphate sorption to polygalacturonate-coated Goethite, Soil Sci. Soc. Am. J., 70, 541-549, 2006.

Muchena, F. N.: Use of soil physical characteristics, for land evaluation, in: Soil Physical Properties and Crop Production in the Tropics, edited bY: Lal, R. and Greenland, D. J., John Wiley and Sons, 427-437, 1979.

Murphy, J. and Riley, J. P.: A modified single-solution method for the determination of phosphate in natural waters, Anal. Chim. Acta, 27, 31-36, 1962.

Murrmann, R. P. and Peech, M.: Effect of $\mathrm{pH}$ on labile and soluble phosphate in soils, Soil Sci. Soc. Am. J., 33, 205-210, 1969.

Nardoto, G. B., Ometto, J. P. H. B., Ehleringer, J. R., Higuchi, N., Bustamante, M. M. D. C., and Martinelli, L. A.: Ecosystems, 11(8), 1234-1246, doi:10.1007/s10021-008-9189-1, 2008.

Nelson, D. W. and Sommers, L. E.: Total carbon and total nitrogen, in: Methods of Soil Analysis: Part 3 - Chemical Methods, edited by: Sparks, D. L., SSSA Book Series No 5, SSSA and ASA, Madison, WI, 961-1010, 1996.

Nierop, K. G. J., Verstraten, J. M., Tietema, A., Westerveld, J. W., and Wartenbergh, P. E.: Short- and long-term tannin induced carbon, nitrogen and phosphorus dynamics in Corsican pine litter, Biogeochemistry, 79, 275-296, 2006.

Nuernberg, N. J., Leal, J. E., and Sumner, M. E.: Evaluation of an anion-exchange membrane for extracting plant available phosphorus in soils, Commun. Soil Sci. Plan., 29, 467-479, 1998.

Nziguheba, G. and Bünemann, E. K.: Organic phosphorus dynamics in tropical agroecosystems, in: Organic Phosphorus in the Environment, editd by: Turner, B. L., Frossard, E., and Baldwin, D. S., CABI Publishing, 243-268, 2005.
Olk, D. C., Cassman, K. G., Schmidt-Rohr, K., Anders, M. M., Mao, J.-D., and Deenik, J. L.: Chemical stabilization of soil organic nitrogen by phenolic lignin residues in anaerobic agroecosystems, Soil Biol. Biochem., 38, 3303-3312, 2006.

Olsen, S. and Sommers, L... Phosphorus, in: Methods of Soil Analysis, 2nd Edition, edited by: Page, A., American Society of Agronomy/Soil Science Society of America, Madison, 403-427, 1982.

Pella, E.: Elemental organic analysis, Part 2, State of the art, Am. Lab., 22, 28-32, 1990.

Pleysier, J. L. and Juo, A. S. R.: A single-extraction method using silver-thiourea for measuring exchangeable cations and effective CEC in soils with variable charges, Soil Sci., 129, 205-211, 1980.

Quesada, C. A., Lloyd, J., Anderson, L. O., Fyllas, N. M., Schwarz, M., and Czimczik, C. I.: Soils of amazonia with particular reference to the rainfor sites, Biogeosciences Discuss., 6, 3851-3921, 2009a, http://www.biogeosciences-discuss.net/6/3851/2009/.

Quesada, C. A., Lloyd, J., Schwarz, M., Baker, T. R., Phillips, O. L., Patiño, S., Czimczik, C., Hodnett, M. G., Herrera, R., Arneth, A., Lloyd, G., Malhi, Y., Dezzeo, N., Luizão, F. J., Santos, A. J. B., Schmerler, J., Arroyo, L., Silveira, M., Priante Filho, N., Jimenez, E. M., Paiva, R., Vieira, I., Neill, D. A., Silva, N., Peñuela, M. C., Monteagudo, A., Vásquez, R., Prieto, A., Rudas, A., Almeida, S., Higuchi, N., Lezama, A. T., López-González, G., Peacock, J., Fyllas, N. M., Alvarez Dávila, E., Erwin, T., di Fiore, A., Chao, K. J., Honorio, E., Killeen, T., Peña Cruz, A., Pitman, N., Núñez Vargas, P., Salomão, R., Terborgh, J., and Ramírez, H.: Regional and large-scale patterns in Amazon forest structure and function are mediated by variations in soil physical and chemical properties, Biogeosciences Discuss., 6, 39934057, 2009, http://www.biogeosciences-discuss.net/6/3993/2009/.

RADAMBRASIL: Levantamento dos Recursos Naturais, Ministério de Minas e Energia, Departamento Nacional de Produção Mineral, Rio de Janeiro, 38 vol., 1978.

Ramalho Filho, A. and Beek, K. J.: Sistema de Avaliacao de Aptidao Agricola das Terras, 3rd edition, EMBRAPA CNPS, Rio de Janeiro, 65, 1995.

Saleque, M. A. and Kirk, G. J. D.: Root-induced solubilization of phosphate in the rhizosphere of lowland rice, New Phytol., 129, 325-336, 1995.

Sanchez, P. A.: Soil productivity and sustainability in Agroforestry systems, in: Agroforestry: a decade of development, edited by: Steppler, H. A. and Nair, P. K. R., International Council for Research in Agroforestry, Nairobi, 205-223, 1987.

Sanchez, P., Palm, C. A., and Buol, S. W.: Fertility capability soil classification: a tool to help assess soil quality in the tropics, Geoderma, 114, 157-185, 2003.

Sattell, R. R. and Morris, R. A.: Phosphorus fractions and availability in Sri Lankan alfisols, Soil Sci. Soc. Am. J., 56, 1510-1515, 1992.

Schmidt-Rohr, K., Mao, J.-D. and Olk, D. C.: Nitrogen-bonded aromatics in soil organic matter and their implications for a yield decline in intensive rice cropping, P. Natl. Acad. Sci. USA, 101, 6351-6354, 2004. 
Schwendenmann, L. and Veldkamp, E.: The role of dissolved organic carbon, dissolved organic nitrogen, and dissolved inorganic nitrogen in a tropical wet forest ecosystem, Ecosystems, 8, 339-351, 2005.

Siegel, S. and Castellan Jr., N.: Nonparametric statistics for the behavioural sciences, 2nd edition, McGraw-Hill, Boston, 1998.

Smeck, N. E.: Phosphorus: An indicator of pedogenetic weathering processes, Soil Sci., 115, 199-206, 1973.

Smeck, N. E.: Phosphorus dynamics in soils and landscapes, Geoderma, 36, 185-199, 1985.

Stevenson, F. J.: Humus Chemistry: Genesis, Composition Reactions, John Wiley \& Sons, New York, 496 pp., 1994.

Stewart, J. W. B. and Tiessen, H.: Dynamics of soil organic phosphorus, Biogeochemistry, 4, 41-60, 1987.

Storie, R. E. and Wieslander, A. E.: Rating soils for timber sites, Soil Sci. Soc. Am. Proc., 13, 499-509, 1948.

Syers, J. K., Williams, J. D. H., Campbell, A. S., and Walker, T. W.: The significance of apatite inclusions in soil phosphorus studies, Soil Sci. Soc. Am. J., 31, 752-756, 1967.

Tiessen, H., Stewart, J. W. B., and Cole, C. V.: Pathways of phosphorus transformations in soils of differing pedogenesis, Soil Sci. Soc. Am. J., 48, 853-858, 1984.

Tiessen, H. and Moir, J. O.: Total and Organic Carbon, in: Soil Sampling and Methods of Analysis, edited by: Carter, M. R., Leis Publ., Boca Raton, FL, 187-199, 1993.

Thomas, M. F.: Tropical Geomorphology, The McMillan Press, London, 331 pp., 1974.

Trolove, S. N., Hedley, M. J., Caradus, J. R., and Mackay, A. D.: Uptake of phosphorus from different sources by Lotus pedunculatus and three genotypes of Trifolium repens 2. Forms of phosphate utilised and acidification of the rhizosphere, Aust. J. Soil Res., 34, 1027-1040, 1996.

Uehara, G. and Gilman, G.: The Mineralogy, Chemistry, and Physics of Tropical Soils with Variable Charge Clays, Westview Press, Boulder, Colorado, 1981.

Van Reeuwijk, L. P.: Procedures for soil analysis, International Soil Reference Information Centre, ISRIC, 6th edition, Wageningen, the Netherlands, 120 pp., 2002.

Vitousek, P. M.: Nutrient Cycling and Limitation: Hawai'i as a Model System, Princeton University Press, 223 pp., 2004.

Vitousek, P. M., Cassman, K., Cleveland, C., Crews, T., Field, C. B., Grimm, N. B., Howarth, R. W., Marino, R., Martinelli, L., Rastetter, E. B., and Sprent, J. I.: Towards an ecological understanding of biological nitrogen fixation, Biogeochemistry, 5758, 1-45, 2002.
Vitousek, P. M., Turner, D. R., Parton, W. J., and Sanford, R. L.: Litter decomposition on the Mauna Loa environmental matrix, Hawaii: Patterns mechanisms and models, Ecology, 75, 418429, 1994.

Vitousek, P. M. and Sanford, R. L.: Nutrient cycling in moist tropical forest, Annu. Rev. Ecol. Syst., 17, 137-167, 1986.

Walker, T. W.: The significance of phosphorus in pedogenesis, in: Experimental Pedology, edited by: Hallsworth, E. G. and Crawford, D. V., Butterworths, London, 295-315, 1964.

Walker, T. W. and Adams, A. F. R.: Studies on soil organic matter, 1. Influence of phosphorus content of parent materials on accumulations of carbon, nitrogen, sulfur and organic phosphorus in grassland soils, Soil Sci., 85, 307-318, 1958.

Walker, T. W. and Adams, A. F. R.: Studies on soil organic matter, 2. Influence of increased leaching at various stages of weathering on levels of carbon, nitrogen, sulfur, organic and inorganic phosphorus, Soil Sci., 87, 1-10, 1959.

Walker, T. W. and Syers, J. K.: The fate of phosphorus during pedogenesis, Geoderma, 15, 1-19, 1976.

Wania, R., Hietz, P., and Wanek, W.: Natural ${ }^{15} \mathrm{~N}$ abundance of epiphytes depends on the position within the forest canopy: source signals and isotope fractionation, Plant Cell Environ., 25, 581589, 2002.

Westin, F. C. and de Brito, J. G.: Phosphorus fractions of some Venezuelan soils as related to their stage of weathering, Soil Sci., 107, 194-202, 1969.

Williams, J. D. H. and Walker, T. W.: Fractionation of phosphate in a maturity sequence of New Zealand basaltic soil profiles: 2, Soil Sci., 107, 213-219, 1969.

Zoysa, A. K. N., Loganathan, P., and Hedley, M. J.: A technique for studying rhizosphere processes in tree crops: soil phosphorus depletion around camellia (Camellia japonica L.) roots, Plant Soil, 190, 253-265, 1997.

Zoysa, A. K. N., Loganathan, P., and Hedley, M. J.: Effect of forms of nitrogen supply on mobilisation of phosphorus from a phosphate rock and acidification in the rhizosphere of tea, Aust. J. Soil Res., 36, 373-388, 1998.

Zoysa, A. K. N., Loganathan, P., and Hedley, M. J.: Phosphorus utilisation efficiency and depletion of phosphate fractions in the rhizosphere of three tea (Camellia sinensis L.) clones, Nutr. Cycl. Agroecosys., 53, 189-201, 1999. 